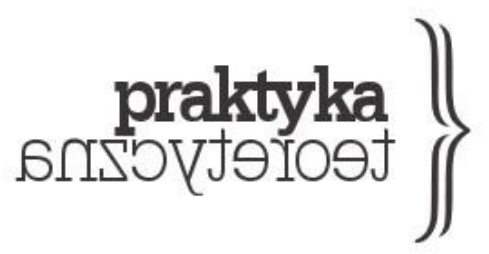

ISSN 2081-8130

DOI: $10.14746 /$ prt.2017.1.2 www.praktykateoretyczna.pl

\title{
PolityCZnOŚć METOdOLOGII A POLITYCZNOŚć PRZEDREWOLUCJI. TOCQUEVILLE, EMANCYPACJA I KRYTYKA KONSERWATYWNEJ HISTORIOGRAFII
}

\author{
GABRIEL KLIMONT
}

\begin{abstract}
Abstrakt: Artykul stanowi próbę krytyki mechanizmów konserwatywnej historiografii na przykładzie wybranych dyskusji w obrębie historii społecznej dotyczących ostatnich lat ancien régime’u. Współczesne spory historyków i historyczek zostają zanalizowane pod kątem metodologicznym i pojęciowym. Celem artykułu jest ufilozoficznienie problemów przypisanych do pola historycznego oraz rozpoznanie ich stawek politycznych. Efektem tych analiz jest wypracowanie bardziej uniwersalnych schematów krytyki narracji konserwatywnej w historiografii oraz przedstawienie paru wskazówek do pisania interdyscyplinarnej historiografii emancypacyjnej, która twórczo czerpałaby z tradycji lewicowej makrohistorii, filozoficznych krytyk historii i historii oddolnej.
\end{abstract}

Słowa kluczowe: rewolucja francuska, Tocqueville, Walter Benjamin, metodologia historii, historia oddolna 
Trup Tocqueville'a nie przestaje straszyć badaczek i badaczy rewolucji. Jego dzieło ożywiane jest przez hegemoniczną historiografię, która sięga po niego w obronie swoich granic. Krok poza nie oznacza konieczność zmierzenia się z Tocqueville'em - zarówno w sferze metodologii (dobór źródeł, stosunek teorii do badań empirycznych, pytania badawcze), sfery zainteresowań (stosunek tego, co polityczne, do innych sfer życia społecznego; relacja makrohistoriamikrohistorie), problemów filozoficznych (sprawczość, podmiotowość, obraz procesu historycznego), społecznych (wizja społeczeństwa) i politycznych. Tocqueville ma wiele twarzy, a jego refleksja składa się z przynajmniej trzech komponentów, które sprawiaja, że jego myśl jest pełna napięć - namysł polityczny pozostaje w ciąłym ruchu między tym, co konserwatywne, liberalne i republikańskie (Marczewski 2012). Z dzisiejszej perspektywy Tocqueville mieści się jednak w szerokim mainstreamie, a dzięki swojej niejednoznaczności staje się jego najmniej tępym obrońca. Wykorzystywany na różnych frontach, na każdym blokuje emancypacyjną refleksję nad rewolucja - konserwatystom pomaga wspierać de Maistre'a, liberalnym historiozofom w stylu Szackiego czy Fureta pozwala na szerszą krytykę rewolucjonistów, republikanom zaś funduje spokój i znieczulenie na ekonomiczne źródło problemów społecznych.

Pierwszym celem tego artykułu jest przedstawienie propozycji demontażu schematów myślenia hegemonicznej historiografii dotyczących okresu przedrewolucyjnego. Drugim celem jest naszkicowanie - w obrębie pytań badawczych stawianych przez hegemoniczną historiografię ${ }^{1}$ - metod, które umożliwiałyby emancypacyjną pracę nad kluczowymi zagadnieniami ostatnich lat ancien régime’u. Artykuł ma także przybliżyć polskim badaczkom i badaczom (niekoniecznie specjalizującym się w dziedzinie badań historycznych) wybrane wątki współczesnych debat toczonych w polu historii społecznej i metodologii badań nad okresem poprzedzającym Wielką Rewolucję Francuska. Pomniejsza ambicją jest tu nie tylko przywołanie i omówienie ciekawych problemów, które wydają się mało obecne w polskiej nauce, ale także wskazanie na te aspekty sporów toczonych przez zawodowe historyczki i historyków ${ }^{2}$, które mogą stanowić punkt wyjścia do badań o charakterze interdyscyplinarnym.

\footnotetext{
${ }^{1}$ Historiografię hegemoniczna (podobnie jak w teorii postkolonialnej) rozumie się tu jako historię pisaną przez zwycięzców, linearną, spójną historiografię dążącą do zachowania status quo, legitymizującą obecną władzę oraz rządząca pamięcią, a więc z konieczności uwikłaną w anachronizmy, które mają kreować wizję dawnych społeczeństwa na podobieństwo obecnych stosunków panowania. Na temat np. zmian w myśleniu o przemocy w Wielkiej Rewolucji Francuskiej zob. Wahnich 2015, Traverso 2014.

Z kolei skupienie na „przedrewolucji” ma na celu rozbrojenie myślenia hegemonicznego, które traktuje Wielką Rewolucję Francuską (oraz jej przemoc) jako „wydarzenie”, wyrwę czy wyłom w długim pochodzie wolności, praw człowieka - czy szerzej - różnego rodzaju tendencji społecznych (Furet 1994). Przedrewolucję rozumiemy więc jako okres ostatnich lat ancien regime’u, którym należy ponownie przywrócić rolę koniecznego kontekstu w badaniach nad Rewolucją, wskazując na ciąłość, a nie zerwanie. Tego rodzaju optyka ma skutecznie uniemożliwiać wywyższanie analizy dyskursywnej (obecnie hegemonicznej) nad analizę materialistyczną (podobny pomysł zob. Wahnich 2015).

${ }^{2}$ Chodzi przede wszystkim o badania Silvii Marzagalli, Gaila Bossengi, Simona Burrowsa czy Vivian Gruder.
} 
Ufilozoficznienie niektórych zagadnień z pola historycznego jest czwartym, ostatnim celem tego artykułu.

Walki w obrębie akademii są czymś bliskim i namacalnym. Nie będziemy o nich zapominać. Cofniemy się jednak do bardziej strukturalnej krytyki koncepcji Tocqueville'a. Spojrzymy nie niego nie od strony konkretnych strać, w których zostaje użyty: skrytykujemy go niejako „od wewnątrz”, respektując przynajmniej niektóre z praw, które sam rozpisał dla swojej myśli. Zwróćmy uwagę, że wszystkie sfery z poprzedniego akapitu (metodologia, zainteresowania, problemy filozoficzne, społeczne i polityczne) dotycza jednak kwestii teoretycznych. Dlatego też naturalnym (ale i dosyć prostym) ruchem byłoby sięgnięcie po inny zestaw pojęć, inną teorię, aby w drugim kroku zastosować ją do walki z Tocqueville'em. Taki sposób pracy nad Dawnym ustrojem i rewolucja zręcznie wymija empiryczność badań. Spróbujemy zrobić odwrotnie: pójść za Tocqueville’em, a nie przeciwko niemu. Przyjrzymy się w ten sposób nie tylko teoretycznym źródłom jego argumentacji, ale popatrzymy na ich materialny, historyczny i konkretny charakter - obejrzymy Francję, o której mówi. Rozejdziemy się z nim dopiero w określonych rozstrzygnięciach historycznych - to tam postaramy się zbudować obraz kontr-Francji, z którym powrócimy na poziom abstrakcji. Bronią przeciwko Tocqueville' owi będzie więc inny obraz ancien régime’u. Dopiero bogatsi o ten nowy rodzaj amunicji ostrzelamy Tocqueville'a na polu teoretycznym. I dopiero to pozwoli nam mieć nadzieję, że trup już na dobre nie podniesie swojej głowy³.

\section{Struktura Dawnego Ustroju i Rewolucji}

Myśl Tocqueville’a funkcjonuje na czterech poziomach ułożonych hierarchicznie: 1) poziom abstrakcyjny (metoda, najogólniejsze schematy myślenia, ukryte założenia teoretyczne),

\footnotetext{
${ }^{3}$ Zamysł teoretyczny, który przyświeca tej pracy, łączy w sobie dwa odmienne, emancypacyjne podejścia do uprawiania historiografii. $Z$ jednej strony chodzi o to, aby uznać mechanizmy tocqueville'owskie za reprezentatywne dla obecnej hegemonii historycznej, a więc także - jak widziałby to Enzo Traverso - polityki pamięci. Neoliberalizm wchodzi dziś w sojusz z argumentacją konserwatywną, zarówno po to, aby stłumić wszelkie mniejszościowe mikrohistorie, jak i po to, aby zwalczyć możliwość innej, lewicowej narracji na poziomie makro. Te dwie wizje emancypacyjnej historiografii - powiedzmy, benjaminowska oraz lewicowa - mimo wspólnego wroga są sobie tradycyjnie obce. Mniejszościowa uznaje spójną narrację lewicową za niebezpieczną i zamknięta, z kolei ta druga oskarża mniejszościowo-benjaminowską o brak sprawczości politycznej, nieumiejętność mobilizacji społecznej.

W poniższym artykule postaram się twórczo czerpać z obu tych tradycji. Nie zignorujemy hegemonicznej historiografii, jak chciałby tego zapewne Benjamin; podążymy za pytaniami badawczymi i polami zainteresowań, które wyznacza nam historiograf-hegemon. Ale krytykując go, sięgniemy do rezerwuaru pojęć i koncepcji, dalekich od makrohistoriii. Efektem tego będzie, być może, odzyskanie określonych pól badawczych, tematów i okresów historycznych dla lewicowej narracji (zob. Traverso 2016; Traverso 2014; Pospiszyl 2016)
} 
2) poziom tez, 3) poziom konkretnych rozstrzygnięć historycznych, 4) poziom mikrohistoryczny (właściwie nieobecny).

\section{a) Abstrakcje. Ontologia i metoda Tocqueville'a}

Cały wysiłek umysłowy Tocqueville’a opiera się na paru głównych schematach. Nie pracuje on na sprzecznościach; jego dobrze naoliwiona maszyna imponuje spójnością, ale nie lubi luk, miejsc ciemnych i niejasnych. Zamiast przepracowywać sprzeczności, Tocqueville uzgadnia symptomy (poziom praktyk) do ogólnych ruchów w społeczeństwie (poziom procesów np. centralizacja administracji). Gest ten jest aktem zrozumienia. Wiedza wydarza się więc dopiero dzięki wpisaniu małych, pozornie niepowiązanych, ale obserwowanych niejako w pierwszym rzucie praktyk społecznych w szerszą całość. Celem jest wkomponowanie fenomenów w idealistyczną strukturę. Gdyby Platon znał pojęcie czasu linearnego, patrzyłby na rewolucję tak jak Tocqueville.

Idealizm Tocqueville'a widać jeszcze wyraźniej, gdy zderzymy go z perspektywa materialistyczna. Spójrzmy na najprostszy schemat marksistowski: konkretne praktyki wydarzają się w świetle ogólnych praw, np. prawa akumulacji kapitału czy subsumcji realnej, sa ich konkretyzacjami, ale pozostaja z nimi w twórczym napięciu. Relacja jest więc obustronna. Konkretne praktyki mają wpływ na ogólne prawa, są abstrakcjami określonymi (Vinci 2014, 85-104), a nie tylko symptomami jakiejś sztywnej, naddeterminującej struktury. W wielu przypadkach relacja ciąży więc nawet w stronę praktyk materialnych - to one bowiem są sprawcze względem praw. Tocqueville nie zna jednak pojęcia abstrakcji określonej, nie potrafi włączyć do swojego myślenia tego, co materialne. Być może część jego myślenia jest dialektyczna, ale jest to dialektyka idealisty.

\section{b) Tezy}

Abstrakcje to wszystko to, co Tocqueville zabiera ze sobą, pochylając się nad materiałem źródłowym. Można na nie patrzeć jako na zestaw narzędzi badawczych i metodologię. Abstrakcje to także ukryte założenia i niejawne schematy myślenia. W odróżnieniu od nich swoje siedem tez Tocqueville wykłada explicite. Każda z nich opiera się na wielu konkretnych praktykach społecznych (konkretyzacjach), które konstruuje z materiałów źródłowych:

1. Właściwym celem zmian rewolucyjnych było obalenie feudalizmu.

2. Centralizacja jako jedyna przeżyła rewolucję.

3. Nadzór administracyjny był rozrośnięty do granic możliwości; jednocześnie sprawczość polityczna leżała po jego stronie. 
4. Roszczeniowy lud miał za dobrze; jednocześnie był on przedmiotem gry podmiotów posiadających polityczną sprawczość.

5. Przed 1789 rokiem istniały dwie Francje: administracyjna, realna choć ukryta, oraz ta en logoi - oświeceniowa, funkcjonująca w obrębie habermasowskiej sfery publicznej.

6. Przed 1789 rokiem zakończyła się pewna faza procesu sekularyzacyjnego. Pustkę po uczuciach religijnych zastapiły uczucia polityczne.

7. Masy, które obserwujemy w przeddzień rewolucji, nie dojrzały do republikańskiej wolności.

\section{c) Konkretyzacje}

Konkretyzacje można określić mianem najmniejszych cząstek, z których Tocqueville buduje obraz ancien régime'u. Jednocześnie są to podstawowe rozstrzygnięcia, jeśli chodzi o interpretacje materiału źródłowego. Dlatego zazwyczaj występuja jako już gotowe praktyki społeczne, które maja jawić się czytelnikowi jako obiektywne fakty. W projekcie Tocqueville'a są podstawowym budulcem historii (idealistycznej struktury), które nabierają sensu dopiero wtedy, kiedy obejrzymy je od strony tez.

Nie dajmy się zwieść tej protopozytywistycznej metodologii (,po prostu” wydarzenia, „po prostu” praktyki społeczne $\rightarrow$ dopiero później interpretacje w świetle procesu makrohistorycznego). Pamiętajmy, że konkretyzacje pozostają w relacji sprzężonej z tezami. Są bowiem wynikiem przerobienia materiału źródłowego przez abstrakcje. Skoro maja służyć uzasadnieniu tez, w naturalny sposób są w ich stronę interpretacyjnie wychylone.

\section{Argumentacja Tocqueville'owska}

\section{Feudalizm}

Pierwszym ruchem teoretycznym Dawnego Ustroju $i$ Rewolucij jest próba odwrócenia naszej uwagi od działań rewolucjonistów w sprawie reformy rolnej. Podkreśla się natomiast rolę, jaką odegrały zmiany, które dokonały się przed rokiem 1789. Gest ten Tocqueville będzie powtarzał jeszcze wiele razy - rola podmiotów rewolucyjnych zostanie osłabiona, jeżeli pokaże się, że społeczeństwo było już praktycznie zrewolucjonizowane w momencie podjęcia działań. Fakt, iż było szybsze od rewolucjonistów, ma świadczyć o ich niedojrzałości, nieumiejętności analiz makrostruktur.

W latach 1770-1790 dochodzi do ogromnego rozdrobnienia własności ziemskiej (ma ona być dwu-, trzykrotnie większa niż za czasów Tocqueville’a). Jedną z ważniejszych konkretyzacji, która ma wspierać tezę o obalaniu feudalizmu, jest stwierdzenie dotyczące 
klasowej redystrybucji zysków w ziemię i kapitał finansowy. Mieszczanie i szlachta lokują swoje oszczędności „w papierach państwowych” oraz „prywatnie na procent”, natomiast chłopstwo przeznacza je na zakup gruntu. Takie myślenie pozwala Tocqueville'owi przemycić bezkrytycznie obserwację Arthura Younga, brytyjskiego podróżnika, który twierdzi, że „połowa ziemi we Francji stanowi ich [chłopów] własność”. Karcąco-zdziwiony ton przybysza z zewnątrz nie jest tu bez znaczenia: ma to być angielski głos umiarkowania i rozsądku.

W drugim ruchu Tocqueville każe nam spojrzeć na wieś od strony pana. Od początku dotyka nas jego bezwolność, brak sprawstwa. Sprawami parafii „kieruje pewna liczba urzędników, którzy nie są wykonawcami woli dworu i których pan już nie naznacza: część z nich mianował intendent prowincji, część wybieraja sami chłopi”. „Szlachta nigdzie nie administruje" (oprócz sądownictwa). Wszystkie sprawy - zostaje to podkreślone wielokrotnie - leżą w gestii władz centralnych. „Pan wsi jest jedynie pierwszym obywatelem”. Strona polityczna przywilejów szlacheckich znika - „pozostaje, a nawet mocno się rozrasta, jedynie sfera pieniężna".

Trzeci krok polega na utwierdzeniu nas w przekonaniu, że Francja przedrewolucyjna jest swego rodzaju ewenementem, w którym dokonało się pewne odwrócenie. Chłopu jest właściwe bardzo dobrze, „wyzwolił się on całkowicie spod rządów swojego pana”, a „pańszczyznę spotyka się rzadko i jest lekka”. Szlachtę mamy natomiast postrzegać poza systemem dominacji, na zewnątrz aparatu administracyjnego - poza strukturą władzy.

Tylko po zinternalizowaniu tego świata na opak będziemy w stanie przyjąc kolejne tezy Tocqueville'a. Pierwsze konkretyzacje szykuja bowiem miejsce na pozostałe - pełnia ważną funkcje przygotowawczą, polegającą na oddaleniu pytań, które zagroziłyby stabilności całej struktury teoretycznej. To z nich właśnie zbudujemy korpus naszych pytań badawczych.

\section{Ludziom było za dobrze}

François Furet w jednym ze swoich artykułów dotyczących ściąania podatków wśród chłopów przedrewolucyjnej Francji dopuszcza się ciekawego zabiegu. Z całą stanowczością stwierdza, że przyczyną chłopskiego niezadowolenia był dyskurs, który nimi zawładnął. Dopiero on bowiem dał im możliwość wyrażenia żalu.

Wiele musiało się zmienić, aby mainstream badań mógł pozwolić sobie na takie tezy. Aplikacja Foucaulta na grunt historii rewolucji dokonała się bowiem rękami liberałów. Zalepili oni w ten sposób lukę, którą wytworzyła schematyczna historiografia marksistowska, nieradząca sobie z tymi wszystkimi czynnikami, które nie dały się wpisać w prosty, ekonomistyczny model. Badania nad rewolucja prosiły się o kulturalizm, były głodne refleksji nad dyskursem. Jednak po przyswojeniu tej refleksji powróciły na drogę dawno już wytyczoną 
przez Tocqueville’a - odległa od krytycznej analizy dyskursu władzy i nadzoru, za to beztroska w swej ignorancji wszystkich czynników materialnych i ekonomicznych.

„Panowanie Ludwika XVI było najpomyślniejszym okresem dawnej monarchii i to właśnie ta pomyślność przyspieszyła rewolucję". Jakie konkretyzacje składają się na tę pomyślność? Tocqueville zaczyna od zmiany w świecie idei - urzędnicy na czterdzieści lat przed rewolucją mają ochotę wszystko zmieniać, poprawiać, ulepszać. Dotyczy to przede wszystkim infrastruktury (budowa sieci dróg) i rolnictwa („niektóre okólniki kontrolera generalnego bardziej przypominaja traktaty o rolnictwie niż urzędowe pisma”). Podatki ściagane są w „łagodniejszy sposób”, przede wszystkim „widać prawdziwą troskę o straszny los ubogich”. Król powiększa wszystkie „fundusze przeznaczone na urządzanie warsztatów dobroczynnych po wsiach”. Wynika to z tego, że władca liczy się z oświeconą opinią publiczną, „która mu co dzień podsuwała pomysły i wciagała go w swój nurt, której się radził, obawiał, której schlebiał nieustannie".

Skarb państwa cierpiał jednak ze względu na ciężar świadczeń socjalnych - zapomóg, subsydiów, wydatków na roboty publiczne. Dlatego rosło zadłużenie u przedstawicieli finansjery, którzy „nigdy nie mogli być pewni zwrotu pożyczki”. Rząd „stał się niewątpliwie największym odbiorcą wytworów przemysłu i największym przedsiębiorcą w królestwie”. Ale ze względu na jego zadłużenie to właśnie warstwa przedsiębiorców była najbardziej wrogo nastawiona do władzy królewskiej. Rewolucję wywołała więc chciwość, a nie nierówności. Jednak ogólnie rzecz biorąc, „w żadnym z okresów porewolucyjnych wzrost ogólnego dobrobytu nie następował szybciej niż w ciagu owych dwudziestu lat poprzedzających rewolucjęe".

\section{Centralizacja}

Metoda Tocqueville’a, zakładająca, że należy patrzeć na ukryte struktury władzy, które niejako z drugiego rzędu i w długim trwaniu zmieniają społeczeństwo, jest widoczna po raz kolejny, gdy poruszony zostaje problem centralizacji. Rada Królewska (Le conseil du roi) rządzi „dyskretnie i po cichu, nie chełpiąc się swoją władzą”, jest elementem implementowanym na różnorodność systemu postśredniowiecznego: wielości podmiotów, korporacji, tytułów; wielości praw, uprawnień, przywilejów; wielości instytucji, sądów, zgromadzeń. W wyobraźni Tocqueville'a Rada jest punktem, w którym ogniskuje się cały proces centralizacji - równolegle wszystkie dotyczące jej konkretyzacje są wspornikami, na których opiera się teza o procesie centralizacyjnym jako idealistycznej strukturze władającej historia. Co więcej, zgodnie z wcześniejszą tezą Tocqueville'a o upłynnieniu porządku klasowego za sprawą upadku „społeczeństwa honoru” i liberalizującej funkcji pieniądza, Rada Królewska odpowiada wymogom nowych czasów: „nie ma tam magnatów, tylko ludzie średniego i niskiego 
pochodzenia [...], dawni intendenci, osoby doświadczone w kierowaniu sprawami państwowymi”. Merytokracja ma zastępować władzę klasową i stanową.

\section{Oświeceniowy pas transmisyjny}

Trzeźwy minimalizm bez wielkich projektów politycznych funduje realistyczną perspektywę, z której patrzyć mamy na marzycieli z Francji. Tym ruchem Tocqueville konstruuje pierwszą konkretyzację, która pomoże później w utrzymaniu tezy: rewolucjoniści to grupa intelektualistów, która chciała aplikować utopię w rzeczywistość. Trudna do formowania, rzeczywista tkanka społeczna stawiała bowiem opór, który złamać trzeba było rozlewem krwi. Kolejni obrońcy społecznego status quo przekonują nas, że rewolucje nie mają nic wspólnego z tym, co immanentne. Nie biorą się z głodu, biedy i cierpienia - zaczynają się w kawiarniach. Najwięcej kawiarni znajduje się w centrum. Tocqueville zręcznym ruchem blokuje wszelką analizę oddolna - jest bowiem idealistą w podwójnym sensie tego słowa. Nie tylko odmawia sprawczości wszelkim czynnikom materialnym, niedyskursywnym, niekulturowym (stosunki produkcji, podziały klasowe, bieda), ale jest też przekonany, że ruch idei odbywa się tylko z góry na dół - z centrum do peryferii, z Paryża na prowincję, od intelektualistów do mas. Powrócimy jeszcze do tego wątku.

Prześledźmy jeszcze kilka konkretyzacji, na których Tocqueville wspiera swoje tezy. Cała intelektualna Francja „dzień w dzień dyskutuje o pochodzeniu społeczeństw i jego pierwotnych formach". Metody prowadzenia abstrakcyjnych dysput przenikają następnie do języka polityki, czyniąc go górnolotnym, ale skrajnie nieużytecznym. Ten dyskurs nie pozwala bowiem nazywać konkretnych problemów społecznych. Jego przedstawiciele „byli tak nieskończenie oddaleni od praktyki, że nie docierało do nich żadne doświadczenie”. Ich idee były więc nieweryfikowalne. „Łatwo nabierali wstrętu do tradycji”, a ich myśl „zstapiła w tłum i tu nabrała konsystencji i temperatury namiętności politycznej, tak, że teorie o naturze społeczeństw stały się codziennym tematem rozmów wszystkich próżniaków, rozpalały nawet wyobraźnię kobiet i chłopów”. Tocqueville zakłada istnienie spójnego pasa transmisyjnego idei oraz to, że idee te funkcjonowały wśród warstw ludowych paralelnie do obiegu elit; czy przynajmniej - że nie zmieniły swego kształtu w procesie przekazu.

\section{Niedorośli do wolności}

Czym jest wolność republikańska, której ideał służy Tocqueville’owi za papierek lakmusowy do badania atomizacji społecznej? „Nie żądajcie, bym analizował to wzniosłe pragnienie trzeba go doznawać”, pisze. „Zjawia się samo w wielkich sercach, które Bóg na jego przyjęcie przygotował; napełnia je i zapala. Duszom przeciętnym, które go nigdy nie odczuły, nikt nie 
wytłumaczy, czym ono jest”. Ta krytyka ma być podstawą dla następnej konkretyzacji: ludzie tak naprawdę nie pragnęli wolności, nie znali jej przecież takiej, jaką powinna ona być. „Sądzili, że kochają wolność, tymczasem okazuje się, że jedynie nienawidzili władcy i pana”. Kolejny raz Toqcueville odmawia aktorom społecznym autonomii - ich moc jest jedynie destruktywna, polega na znoszeniu nierówności, czyli ujednolicaniu różnorodności. Te dwa pojęcia nierówność i różnorodność, pozostają u Tocqueville’a w niebezpiecznie bliskim związku. W ten sposób z analiz znika cena, źródło i szkodliwość nierówności - są one postrzegane zawsze jako wartość.

Lud po raz kolejny jest uosobieniem bierności, politycznego nierozeznania i głupoty. „Ponieważ od stu czterdziestu lat ani na chwilę nie pojawił się na politycznej widowni, nikt absolutnie nie wierzył, że się na niej kiedykolwiek pokaże". Powodem wrzenia przedrewolucyjnego jest dla Tocqueville’a dyskurs - klasy panujące, owładnięte zapałem Oświecenia i modernizacji, mówią głośno o problemach społecznych. To z kolei uruchamia mechanizm demaskacji - idee odsłaniaja rzeczywistość wcześniej zakryta, w której klasy podporządkowane żyły w fałszywej świadomości, mylnie rozpoznawały warunki swojego społecznego funkcjonowania. Przejrzawszy na oczy, domagają się zmian. Zwróćmy uwagę, że po raz kolejny mamy do czynienia z ruchem tylko pozornie oddolnym. Sprawczość nadal pozostaje po stronie klas panujących, odpowiedź mas jest tylko ceną, jaką elity płaca za zły ruch, jest konsekwencją dominacji jednego z członów wiązań hegemonicznych (oświeceniowego) nad innymi.

\section{Sekularyzacja}

„Rewolucja Francuska jest więc rewolucją polityczną, która działała sposobami rewolucji religijnej i poniekąd przybrała jej wygląd. [...] A przecież bezbożność stała się wówczas źródłem nieobliczalnego zła społecznego". Tocqueville przyzwyczaił nas już do konserwatywnego schematu, w którym rewolucje wywoływane są przez idee, a nie przez czynniki materialne. Schemat ten ma nas trzymać daleko od pytań związanych z immanencją ma odsuwać pytanie o chleb. Ale ta specyficzna wojna idei - rewolucja religijna - może wydarzyć się dopiero wtedy, kiedy podstawy religii zostaną zachwiane. Pewien etap procesu sekularyzacji musi dobiec końca. Proces ten Tocqueville zarysowuje podobnie jak dzisiejsza myśl komunitariańska (zob. C. Taylor 2007). U progu nowożytności mamy więc do czynienia ze specyficznym odklejeniem praktyk religijnych i ich sensu. Znajdujemy się w centrum lutrowskiej krytyki sakramentu i rytuału - są one jedynie rusztowaniem zasłaniającym istotę wiary, której znaczenie można wyłożyć językiem oderwanym od praktyk lokalnych, świąt, postanowień eklezji, gestów. Teoria sekularyzacji widzi ten proces niczym przewracające się 
kostki domina. „Sola scriptura” wybija znaczenie etyczności, ale w następnym kroku, walcząc $z$ zabobonem, niebezpiecznie zmierza w stronę racjonalizmu. Tomasz Morus jest w stanie skonstruować dobrą wspólnotę chrześcijańska, w której nikt nie zna Chrystusa. Gdy Jezus przybywa do Utopii, cieszy go widok świata, w którym ludzie żyją zgodnie z jego naukami - ich źródło jest jednak odmienne, wynika z naturalnego rozumu.

Myśl Tocqueville’a podąża tą samą drogą. „Duch badawczy zaczął wśród rozmaitych tradycji chrześcijańskich oddzielać prawdziwe od fałszywych”. Krytyka sakramentu i praktyk religijnych oznaczała krytykę języka, w którym się wydarzały - krytyka ta zniszczyła misterną tkankę kultury dawnej, podważyła język symboli i nawiązań. Zapytała o sens mitu, tym samym go zabijając. „Po herezji przyszedł brak wiary”. Schemat sekularyzacyjny jest potrzebny Tocqueville' owi, aby utrzymać pewną wizję klas podporządkowanych. Stanowią one rezerwuar odruchów społecznych, wcześniej zagospodarowany przez religię. W przededniu rewolucji, po upadku religijności, rezerwuar ten zostaje nadkodowany przez namiętności utopijne i oświeceniowe. „Pracowano gorliwie i nieustannie nad odebraniem duszom napełniającej je wiary i zostawiono je puste". Myślą Tocqueville'a kieruje ukryty funkcjonalizm. Oddolni aktorzy nie mogą zmienić swojego miejsca w obrębie systemu, zmianie może ulec jedynie język, którego używają, ale i on zostaje ostatecznie zredukowany do namiętności - lud musi być przecież porywczy; treść i przyczyna tych emocji nie maja już znaczenia dla dalszej analizy. Samo uzgodnienie z wyższą strukturą teoretyczną ma nam służyć za źródło wiedzy.

\section{Uwaga metodologiczna: konserwatywna mitologia republikanizmu}

Jak trzeźwo w którymś miejscu zauważa Tukidydes, historii należy wyznaczyć w pewnym momencie punkt początkowy - opowieść nie może nie zaczynać się skądś. Ale to, co przed opowieścia, przed czasem, wchodzi jednak w relację z główna narracja - jest potrzebne opowieści właśnie dlatego, że jest rezerwuarem obrazów, a nie słów. Obrazy te, mity, założenia da się wykorzystywać jako uzasadnienie tego, co robi się w porządku narracyjnym.

Dla myślenia Tocqueville'owskiego takim bezczasem są początki nowożytności, kiedy to szlachta miała praktykować swoją wolność w obrębie małych wspólnot i instytucji republikańskich. Proces centralizacyjny jeszcze się nie rozpoczął - świat polityczny był statyczny, a światło peitho nie padało tylko z jednego źródła, z centrum. Nie chodzi jednak o samo wypełnianie tej utopii, ale o jej funkcję w wywodzie głównym. Uchwycenie tej funkcji powinno wzmóc $\mathrm{w}$ nas konieczną ostrożność metodologiczną, z której nie możemy zrezygnować, nawet jeżeli mamy zamiar śledzić wywody Tocqueville’a na jego prawach. Spróbujmy więc i teraz skrytykować go z wnętrza machiny konserwatywnej. 
Taką możliwość daje nam analiza schematów Reinhardta Kosellecka. Zwróćmy uwagę, że w jego konserwatywnej krytyce nowoczesności szczególny nacisk położony jest na „motywiarność” kultury dawnej - to właśnie ona pozwala na zbliżanie (czy raczej na trwanie w nieokreślonym dystansie) tego, co teraźniejsze, z przeszłością (zob. jego opis sytuacji, w której Wilhelm Bawarski rozpoznaje siebie jako Aleksandra Wielkiego; Koselleck 2001). Takie ujęcie jest potrzebne, aby uderzyć w zmiany emancypacyjne, które nastapiły później w analizach Kosellecka istotne miejsce zajmuje pokój westfalski. Jest on pierwszym prawdziwym „pokojem ziemskim”, w którym to po serii krwawych walk religijnych i sporów teoretycznych Europa po raz pierwszy wysyła w dalszą przyszłość koniec świata (przedtem mieliśmy do czynienia ze swoistym monopolem na apokalipsę. Ogromne możliwości osadzania wizji i wyobrażeń w przeszłości wiązały się z zakazem kształtowania ich w czasie, który miał nadejść). Od teraz świeckie państwa stają się odpowiedzialne za trwanie świata ziemskiego, muszą więc obmyślić dla niego jakiś rozumny ład. Efektem tego jest zmiana proporcji między przeszłością a przyszłością. Nasza „przestrzeń doświadczenia” kurczy się, ponieważ nie rozpoznajemy się już w motywach ustanawianych przed nami - muszą one zostać aktualizowane, aby zniwelować dystans. Z kolei „horyzont oczekiwań” zostaje otwarty, i to przyszłość staje się przestrzenią, do której przenoszą się myślenia nieznające umiejscowienia utopie. Starożytność do osiemnastego wieku jest kształtowana dowolnie: może być obrazowana na potrzeby „zwierciadła” dla władcy, państwa idealnego czy moralnego przykładu. Przełom następuje wtedy, gdy modele teoretyczne, które mają za zadanie krytykować aktualne społeczeństwa, nawiązują tę relację przez przyszłość. Tak jest z resztą do dziś.

Paradoksalnie aparat teoretyczny Tocqueville’a pochodzi jednak sprzed „czasu siodła” - okresu przejściowego, który Koselleck datuje około 1750 roku. W tym sensie Tocqueville nadal operuje przedczasem, który idealizuje, osadzając w nim swoją konserwatywną mitologię republikanizmu. Pełni ona jednak bardzo podobną funkcje jak nowoczesne utopie wydarzające się w przyszłości - ma być rodzajem punktu, w którym przecinają się wektory, linie dostrzegalne w obecnym społeczeństwie, ale przede wszystkim punktem oceny, standardem, który uległ degradacji. Mitologia Tocqueville’a jest mitologią upadku.

W jaki sposób rozbrajać takie machiny teoretyczne? Wiedza o tym, jak pracują, nie daje automatycznie narzędzia, aby je zatrzymać. Zobaczmy to na przykładzie perwersyjnej, konserwatywnej metody filozofa-faszysty, Carla Schmitta. Śledząc genealogię nowoczesności, Schmitt pokazuje, że wszystkie najważniejsze pojęcia polityczne są właściwie zdegenerowanym produktem wcześniejszych, źródłowych pojecć. „Walka” i „pokój” zostały zakamuflowane przez „konkurencję” i „dyskusje””; „Wola” przekształciła się w „ideał” i „program”; „naród” stał się „publicznością”, „siła roboczą”; „władza” została „propaganda” lub „oddziaływaniem na masy" (Schmitt 2012). Ta fałszywa genealogia każe nam wierzyć, że w mitycznym 
przedczasie istniała prawdziwa polityka. Tocqueville jest tu o wiele mądrzejszy: dostrzega oczywiście rzeczywistą zmianę, powiela jednak błąd konserwatywnej machiny przedczasu. Ale żeby ją zniszczyć, trzeba być uzbrojonym w innego rodzaju metodologię.

Jedną z nich dostarcza nam Massimiliano Tomba, każący śledzić różne czasowości, które dopiero w kolejnym kroku są synchronizowane przez kapitał (Tomba 2013). Jeden liniowy czas historii A, historii 1., jest więc czasem panujacych (Bednarek 2015, Krzeski 2015). Zestawienie ze sobą dyskusji o niewolnictwie sprzed i po rewolucji francuskiej dobrze obrazuje ten przykład - przed rewolucja pytano: skoro chcemy wolności, jak to możliwe, że nie damy jej niewolnikom tu i teraz? Należą oni przecież do tego samego gatunku ludzi. Po rewolucji i ustanowieniu czasu liniowego można było już zastosować argument: oni są na wcześniejszym etapie rozwoju, tam czas modernizacji jeszcze nie nadszedł. Ale to, że następuje uczasowienie pewnych kategorii w odniesieniu do jednej linii, nie oznacza, że przed tym zabiegiem kategorie te były źródłowe - że wyrażały jakieś czyste, nieskrępowane pojęcia polityczne, będące odbiciem prawdziwej polityki.

Każdy konserwatywny przedczas można u-ruchomić, wyrwać go z jego pozornej statyczności. Wystarczy spytać, jakie czasowości musiał stłumić, aby pojawić się jako jeden; które wielościowe ruchy zwalczał, by zachować spokój; jakie mechanizmy bezpieczeństwa wypracował, by nie było śladu walk, z których wyrósł; co musiało zostać zakwalifikowane jako hałas, by co innego mogło być dyskursem.

\section{Wielość przedrewolucji. Szkicowanie emancypacyjnej historiografii}

Hegemoniczna historiografia wyznaczała nam pewne pola: wejdźmy więc w nie i z ich wnętrza zadajmy pytania badawcze, w nadziei, że rozsadzą cały projekt od środka.

W pierwszym ruchu pochylimy się nad gospodarką ancien régime’u, aby obalić teorię „skapywania dobrobytu”, która powiela Tocqueville. Spytamy więc, kto był beneficjentem wzrostu gospodarczego Francji. Szkic rozkładu bogactwa pozwoli nam określić, kto korzystał na inwestycjach w infrastrukturę, uwidocznić rolę starych rodów i wielkiej finansjery oraz ocenić rolę świadczeń socjalnych w wydatkach państwa. Spróbujemy też naszkicować odmienną, bardziej polityczną wizję relacji chłop-pan. Spytamy także o sposób alokacji oszczędności w zależności od miejsca zajmowanego w strukturze klasowej. Pozwoli to zobaczyć, że pozycja szlachty była wciąż bardzo mocna, a wywyższenie mieszczaństwa do roli kategorii było zabiegiem teleologicznym, potrzebnym, by utrzymać myślenie o procesie rewolucyjnym. Spróbujemy także pokazać, w jaki sposób badać stopień petryfikacji społeczeństwa ostatnich lat ancien régime’u. Czy możliwa jest inna perspektywa, która zwróci uwage na procesy społeczne poza struktura administracyjna, niedostrzegane przez 
Tocqueville'a? Jak wygląda relacja pieniądza i prestiżu, i czy te dwa porządki władzy sa rzeczywiście niekomplementarne i następujące po sobie (stabilny czas przywilejów i honoru $\rightarrow$ czasy mobilności społecznej opartej na wyzwalającej funkcji pieniądza)? Wreszcie: jaką rolę pełnią w przedrewolucyjnej Francji poszczególne grupy społeczne, w szczególności korporacje (corps), które Tocqueville postrzega jako obumarłe, średniowieczne relikty? Wszystkie te pytania służą poszukiwaniu śladów autonomii i znajdują się w kontrze do tezy o procesie centralizacji.

Następnie zapytamy o rzeczywisty wpływ idei oświeceniowych na społeczeństwo francuskie ostatnich lat ancien régime’u. Czy można w ogóle mówić o hegemonii intelektualistów (w sensie gramsciańskim) i o spójnym, dominującym dyskursie? Jakimi debatami żyła przedrewolucyjna Francja, jaki był ich zasięg i rozkład klasowy? W jaki sposób bronić tezy o innych, materialnych przyczynach rewolucji? W jaki sposób opisać ówczesną „wiedzę o rządzeniu”, tak aby wyminąć fałszywy dylemat konserwatyzmu, który każe przeciwstawiać Realpolitik zawsze utopijnemu myśleniu emancypacyjnemu? Kolejne pytanie będzie dotyczyło odmiennej wizji sekularyzacji oraz możliwości subwersywnych w obrębie pozornie jednolitego kodu: czy ten sam język religijny może być wykorzystywany przez elity do odgórnego nadzoru, a przez masy do oddolnego oporu lub do - jej właśnie szukamy emancypacji? Wokół jakiego kodu krąży wyobraźnia religijna warstw ludowych? Jakie jest jej przełożenie na sferę polityczną i jaką rolę odgrywa w niej rytuał?

Ostatnie pytanie będzie dotyczyło najważniejszego źródła, na jakim pracuje Tocqueville: kajetów zażaleń. Zobaczymy, jaki obraz oddolnej Francji widać w zeszytach skarg oraz które elementy tego obrazu wchodzą w jawną sprzeczność z rozpoznaniami Tocqueville'a. $\mathrm{Na}$ koniec jeszcze raz powrócimy do problemu „bierności ludu”. Rozpatrzymy serię mikrokonfliktów, które przetoczyły się przez sferę publiczną w ostatnich latach ancien régime’u, i spróbujemy ulokować je na tle wydarzeń politycznych. Pochylimy się też nad przykładami dwóch wiosek, w których mieszkańcy autonomicznie spisali swoje wizje polityczne, utrzymując jednocześnie związki z tym, co działo się w centrum Francji. Kolejny raz powróci tu kwestia krążenia informacji i idei. Spróbujemy określić, w których momentach pas transmisyjny mógł zostać złamany, a informacja $z$ centrum przechwycona i przekierowana do punktów lokalnych.

\section{Dystrybucja dobrobytu}

W przeddzień rewolucji Francja była najludniejszym państwem Europy (w 1715 roku 22 miliony mieszkańców, w 1789 - 28 miliony) (Marzagalli 2015). Jeśli jednak chodzi o procentowy wzrost liczby ludności, to dla Francji wynosi on $30 \%$ i jest to wynik poniżej europejskiej średniej (60\%). Dane te stawały się czasem argumentem na rzecz tezy, że czynniki demograficzne nie powinny być brane pod uwage jako przyczyny rewolucji. Jednak naszą 
uwagę powinny przykuć zupełnie inne wskaźniki. W interesującym nas okresie powoli, ale stabilnie spadała śmiertelność dzieci, chociaż i tak prawie połowa z nich nie dożywała wieku dorosłego (Dupâquier, Sauvy i Le Roy Ladurie 1988). Drugim ważnym czynnikiem był brak epidemii i innych kryzysów populacyjnych. Ostatnia wielka plaga miała miejsce w Marsylii w 1720 roku (Carrière, Courdurié i Rebuffat 1968). Presja demograficzna wpływa na wzrost grupy określanej mianem „ludzi luźnych”, migrujących za praca (głównie okresowo) ze wsi do miast. W ostatnich latach ancien régime'u stopień urbanizacji nie przekraczał 20\%, z czego dużą część stanowiła mocno sprekaryzowana, niepewna jutra grupa społeczna. Proces prekaryzacji ${ }^{4}$ widać też, kiedy przyjrzymy się wiekowi wstępowania w związek małżeński wydłuża się on dla wszystkich grup społecznych od mieszczan w dół (Marzagalli 2015).

W latach 1730-1780 da się zaobserwować wzrost cen produktów rolnych. Odpowiedzią posiadaczy ziemskich jest podwyższanie czynszów za użytkowanie ziemi. W tym okresie ich wysokość podwaja się (Weir 1991). W związku z faktem, że płace w rolnictwie rosną zdecydowanie wolniej niż $w$ innych sektorach, oraz ze zwiększającymi się opłatami za mieszkania w dużych miastach, ogromna ilość ludzi żyjących z własnej pracy absolutnie nie była beneficjentami wzrostu gospodarczego - była jego ofiarami.

Strukturalne rozdrobnienie i zróżnicowanie gospodarki francuskiej utrudnia stawianie jakichkolwiek całościowych tez (Weir 1991). Beneficjentami wzrostu gospodarczego byli najwięksi posiadacze ziemscy i kupcy z elit miejskich oraz tzw. negociants, odpowiedzialni za handel z koloniami. Ich pozycja ekonomiczna zależała od skali spekulacji (najczęściej na zbożu) oraz - co będzie nas interesowało później - od możliwości wpływu na przekierowywanie prawa w stronę logiki zysku. Głód przedrewolucyjny nie był spowodowany kataklizmami i wybuchem epidemii - wywołali go spekulanci.

Produkty rolne wciąż były decydującym elementem w krwiobiegu gospodarki Francji. Historycy, którzy skupiają się na rozwoju handlu kolonialnego i inwestycjach w przemysł, dają się ponieść wizji wzrostu w sektorach, których wpływ był wciąż bardzo niski. Powielają po raz kolejny angielski schemat rozwojowy. Tocqueville myli się, kiedy opiewa wzrost przedsiębiorczości wśród mieszczaństwa, przeszacowuje też rolę inwestycji whandel i przemysł: w ostatnich latach przed rewolucja wszyscy (nawet burżuazja miejska) lokowali swoje oszczędności przede wszystkim w ziemię. Wciąż była to najbardziej stabilna forma zysku (Doyle 1980). Dlatego ceny w rolnictwie były czynnikiem o najszerszym zakresie wpływu i to one także - chociaż nie mechanicznie - przekładały się na wzrost napięć politycznych.

Kiedy przyjrzymy się gospodarce francuskiej przed 1789 rokiem, zobaczmy, że teza o spójnym rozwoju kapitalizmu i przedsiębiorczego mieszczaństwa jest nie do utrzymania.

\footnotetext{
4 Termin ten może zostać uznany za anachronizm; wydaje się jednak, że jest to reakcja dość specyficzna dla polskiego pola historycznego. $\mathrm{Na}$ temat użyteczności pojęcia „prekaryzacji” dla badań historycznych zob. De Vito 2016.
} 
Tocqueville popełnia podobny teleologiczny błąd jak stara historiografia marksistowska. Zamiast jednego makroruchu ujednolicenia mamy raczej do czynienia ze skomplikowana siecią mikrokonfliktów oraz z heterogenicznymi grupami interesów, które często nie zajmuja stanowiska wobec problemów strukturalnych - sa zbyt głęboko zanurzone w kontekście lokalnym. Dopiero rozpoznanie tych kontekstów umożliwia naszkicowanie zmian społecznych. Metoda Tocqueville'a - uzgadnianie fenomenów z ogólniejszymi strukturami idealnymi - nic nie wyjaśnia, a jedynie zaciemnia obraz. Przyjrzyjmy się krótko posiadaczom ziemskim i ich stosunkowi do centralizacji. Patrząc przez pryzmat relacji z kapitałem (posiadacze), pozornie grupa wydaje się jednolita - w jej obrębie jednak funkcjonuja zupełnie różne grupy interesu. Elita stara się doprowadzić do ujednolicenia prawa handlowego i zniesienia ceł wewnętrznych (między prowincjami), ponieważ stopień zakumulowanego kapitału jest tak duży, że cła stają się barierą ograniczającą monopolizację. Jednocześnie elita ta walczy o utrzymanie jednostkowych przywilejów handlowych oraz sprzeciwia się zmianom dotyczącym spójnego opodatkowania dużej własności ziemskiej (Morrisson 2007).

Burżuazja i mniejsi kupcy korzystaja z kolei na różnorodności lokalnej ustawodawstwa. Bariery i ograniczenia chronią ich przed monopolistami, a różnice w cenach pozwalaja im na spekulację (na mniejszą skalę). Zasięg ich oddziaływania politycznego jest ograniczony do jednej czy dwóch prowincji, ich oczy i starania nie są skierowane na Paryż. Nie zmniejsza to jednak zaangażowania i w żadnym wypadku nie prowadzi do atomizacji. Dobrym przykładem jest też elita kupców z Marsylii, która czerpie korzyści z handlu kolonialnego. Niektórzy historycy postrzegaja rozwój obrotu towarami kolonialnymi jako bodziec do rozwoju kapitalizmu i przedsiębiorczości końca siedemnastego wieku. Widać jednak wyraźnie, że kapitał $z$ handlu atlantyckiego nie wchodzi do obiegu kapitału na kontynencie - kupcy z Marsylii zarabiają na wysyłaniu towarów dalej, do innych stolic europejskich, po czym reinwestuja pieniądze w koloniach, przeznaczaja je na towary luksusowe lub inwestują je w prestiż, kapitał symboliczny. W każdym z tych przypadków zyski z handlu kolonialnego „odbijaja sie” od systemu gospodarczego kontynentu, opartego na posiadaniu ziemi - nie wchodzą do schematu krążenia kapitału we Francji (Marzagalli 2011).

Na stawki polityczne w obrębie gospodarki francuskiej należy więc patrzeć inaczej niż Tocqueville. $\mathrm{Z}$ poziomu makro/strukturalnego/molarnego widać niewiele ruchów, które mówią coś o życiu społecznym. Podmioty w bardzo małym stopniu skupiają się na kształtowaniu lub reformowaniu struktury - chcą raczej ulokować się w jej punktach przecięcia, aby móc kontrolować przepływy związane z jej skomplikowaniem i różnorodnością.

Ceny produktów rolnych pozostaja centralnym czynnikiem kształtującym napięcia polityczne. Ich wzrost doprowadza do tak zwanej „reakcji feudalnej”, czyli podwyższenia świadczeń za użytkowanie gruntów (w okresie od 1726-1750 do 1781-1787 podwójnie) (Weir 
1991). Weźmy pod uwagę, że większa część francuskiego chłopstwa nie jest w stanie wyżyć ze sprzedaży produktów wytworzonych na własnej ziemi i zmuszona jest do pracy poza swoim gospodarstwem. Ze względu na zwiększenie opłat następuje zmiana stosunków własnościowych na wsi - chłopi sprzedają swoją ziemię i zasilają grupe „ludzi luźnych”, wciąż ubożejących, ponieważ płace rosną wolniej od cen żywności.

Widać więc wyraźnie, że Tocqueville myli się, nie potrafiąc rozpoznać sieci stosunków na wsi. Wątki feudalne są o wiele bardziej istotne, niż można by się tego spodziewać. Pieniądz wkracza w wiejskie stosunki społeczne, ale nie jest czynnikiem, które kształtuje je bezpośrednio - polityczna siła pana jest wciąż o wiele ważniejsza od jego kapitału symbolicznego czy ekonomicznego. Zwróćmy uwagę, że gdy brakuje mu kapitału ekonomicznego (wzrost cen artykułów rolnych), jest w stanie bardzo szybko przekuć swój kapitał polityczny w ekonomiczny (reakcja feudalna). Co więcej, ten ruch polityczny elity panów jest zamknięty, nie ma konsekwencji finansowych dla innych grup - na podwyższeniu rent nie korzysta aparat państwowy, zyski trafiają bezpośrednio do elit (10\% ziemi znajduje się w posiadaniu Kościoła, około 30\% należy do szlachty, 25\% do burżuazji miejskiej; Marzagalli 2015). Państwo nie wzbogaca się nawet pośrednio - jeżeli podwyższa podatki, to tylko te, które płacą chłopi, nie zyskuje więc na rosnącej zamożności elit.

\section{Przedrewolucja walk klasowych}

Jesienią 1788 roku, kiedy decyzja o zwołaniu Stanów Generalnych już zapadła, przewodniczący Izby Handlowej w Montpellier zdecydował się napisać do króla list, w którym przestawił pewną śmiała propozycję5 (Clay 2015). W okresie między czerwcem 1788 i styczniem 1789 roku Francja wrze - mamy do czynienia z około ośmiomaset nowymi pamfletami politycznymi, z których znaczna większość zawiera postulaty podwojenia ilości przedstawicieli Stanu Trzeciego oraz wprowadzenia systemu głosowania „od głów” a nie „w kolejności”. Przewodniczący chce jednak przekonać króla do zupełnie innego pomysłu. Uważa, że przedstawiciele la commerce powinni mieć swoje własne, odrębne przedstawicielstwo; wybrzmiewaja tu bardzo patriotyczne argumenty - kupcy sa najbliżej krwiobiegu Francji i dlatego posiadają wiedzę o funkcjonowaniu państwa, której brakuje samemu państwu. Są w stanie uratować społeczeństwo przed upadkiem, a skarb przed bankructwem. Sa gwarantem reform, które zapewnią dobrobyt. Przyznaja oczywiście, że „w naszych historycznych annałach, nie znajdziemy przykładu wybierania przedstawicieli handlu do Stanów Generalnych", ale ich argumentacja idzie w inną stronę. Czasy się zmieniły, a wraz z nimi Francja. Dlatego też strategia geopolityczna powinna „uwolnić się spod ciężaru tyranii

\footnotetext{
${ }^{5}$ Treść listu podaje Lauren R. Clay (Clay 2015).
} 
feudalnej”, która reprezentuje „nieszczęśliwy okres problemów i ignorancji”. Rozwiązaniem ma być włączenie burżuazji do polityki.

Z jakiego rodzaju tekstem mamy w tym wypadku do czynienia? Tocqueville szedłby tu ramię $w$ ramię $z$ naiwną metodologia marksistowska. Widziałby w nim głos nowej, przedsiębiorczej grupy, która urosła w siłę i niedługo obali walący się gmach polityczny. Takie odczytanie jest potrzebne, by uzasadniać teorie dalekiego zasięgu, ale wikła się ono w pewien ważny błąd. Nie czytamy bowiem tekstu grupy dominującej, łatwego do analizy w kategoriach makrohistorii, ale „tekst słaby”, rodzaj „literatury mniejszej”, który nie został uznany przez mainstream. „Czwarty Stan” nie wydarzył się, a głos kupców-przedsiębiorców nie został wysłuchany. Stało się tak, ponieważ grupa ta była na tyle słaba, że można ją było zignorować. Nie czytamy więc tekstu hegemonicznego, ale taki, który swoim istnieniem wskazuje na istniejącą hegemonię, bije w nią. Słabość i rozdrobnienie kupców-przedsiębiorców sprawia, że próbują oni forsować nowy dyskurs merytokratyczny. Ich rzeczywisty wpływ ogólnonarodowy, centralny - w porównaniu ze starymi grupami feudalnymi (posiadaczy ziemskich, szlachty) jest jednak bardzo mały (Bossenga 1988). Zakres ich działań jest raczej lokalny, ogranicza się do politycznych manewrów w obrębie regionu, które moga przynieść zysk. Jednak wielkie zyski i wielkie zmiany prawne dotyczące gospodarki leżą w gestii „,starych grup społecznych”. Błędny jest więc schemat rozumowania: „odklejenie reprezentacji politycznej od rzeczywistej siły sprawczej”, mówiącego o tym, że przywileje są już „puste”, bo „w rzeczywistości” Francją kieruje już nowa grupa, burżuazja. Być może takiej burżuazji w ogóle nigdy nie było ${ }^{6}$.

Jednym z największych mitów potocqueville'owskich jest wiara w proces, który wyłaniał nową, spójną grupe społeczną na bazie modelu zakładającego, że zyski z handlu lokowane są w produkcję, co skutkuje bogaceniem się i wzrostem znaczenia nowej klasy przedsiębiorczej. Możliwe, że jest to po prostu pewna kalka angielska, kolejny raz bezmyślnie zastosowana do przypadku Francji. Tu jednak sprawy miały się zupełnie inaczej. Do starej struktury społecznej dołączony zostaje obieg pieniężny, w tym sensie, że kapitał finansowy kupców jest automatycznie przekuwany na kapitał symboliczny, zapewniający awans klasowy. Pieniądz nie niszczy jednak porządku klasowego. Wszyscy nadal inwestują swoje zyski w ziemię; zyski z handlu nie są w większości przypadków reinwestowane w produkcję ze względu na zbyt duże ryzyko - o wiele bardziej opłaca się kupić ziemię, urząd lub tytuł szlachecki (Lucas 1973, 84-126; Marzagalli 2015). Szlachta nie traci jako grupa społeczna, obserwujemy natomiast ruch odwrotny - wszyscy chcą zostać szlachcicami; w osiemnastym wieku odnotowano 6-7 tysięcy kupionych tytułów szlacheckich. Do 1789 roku „nowi szlachcice” stanowili prawie $1 / 6$ całej szlachty.

\footnotetext{
${ }^{6}$ Zob. badania, które wykonała Sarah Maza (Maza 2013).
} 
Jednak podział klasowy idzie na wskroś tego podziału „prestiżowego” i badaczki powinny go szukać w bliższej relacji do kapitału. Sprzedaż urzędów reperuje skarb państwa, ale uruchamia też dwa mechanizmy dystynkcji, którymi stare grupy rządzące bronią się przed zalewem - istniejącego przynajmniej na piśmie - awansu społecznego. Jeden mechanizm dystynkcji to mechanizm czysto ekonomiczny, drugi wiąże się ze skomplikowanymi relacjami prestiżu. Pierwszy omówimy teraz, drugim zajmiemy się przy okazji dekonstrukcji pojęcia jednolitej „szlachty” (Lucas 1973).

Szef Izby Kupieckiej w Montpellier miał swoje odpowiedniki w wielu innych miastach, które nie zawiązały nigdy sojuszu przeciw elitom ekonomicznych, ponieważ w systemie gospodarczym, w którym wpływ na zmianę określa bliskość w stosunku do króla oraz sieć przywilejów, miasta rywalizują ze sobą o dostęp do zasobów (Bossenga 1988). Skutecznie nie pozwala to na wytworzenie świadomości grupowej, wspólnej świadomości politycznej czy klasowej (Greenfeld 2001). Taką świadomość posiadają natomiast elity szlacheckie i finansowe: mniejsze, nierozproszone, o większym dostępie do ośrodków decyzyjnych. To one trzymają w swoich rękach sektory kluczowe dla gospodarki, takie jak przemysł ciężki, wydobycie węgla, produkcję żelaza czy handel kolonialny (jak w przypadku Marsylii) (Chaussinand-Nogaret 1987). Przede wszystkim maja jednak ziemię.

Operowanie dystynkcją klasową ze względu na relacje do kapitału pozwala także dostrzec, w jaki sposób obie grupy - elita i „burżuazja” - operuja dyskursem ekonomicznym. Jeśli będziemy analizowali sam dyskurs „leseferystyczny” lat siedemdziesiątych i osiemdziesiątych, jakby byl on lustrem procesów klasowych, prześlepimy obraz społeczeństwa końca ancien régime’u. Ten błąd popełnia także Tocqueville. Tymczasem nowe dyskursy - merytokratyczne, leseferystyczne - nie sa oznaką dominacji merytokracji i leseferyzmu. Są rezerwuarem, z którego grupy społeczne czerpią, aby realizować swoje materialne interesy. Gdy trzeba chronić się przed zakusami elit, lokalni kupcy bronią ceł i regulacji w imię tradycji, występuja przeciwko leseferyzmowi. Gdy domagają się akcesu politycznego do centrum władzy, wykorzystują myślenie merytokratyczne do określonego celu. Podobnie elity: czasem dyskursy starych praw pozwalaja im na zachowanie monopolu, w innych przypadkach odwrotnie - logika akumulacji kapitału domaga się leseferyzmu, by elity mogły poszerzyć monopol. Sugestia, że jeden dyskurs rządzi światem społecznym Francji, jest iluzją wynikającą z idealistycznej metodologii Tocqueville'a.

Jednym z ważnych przykładów wykorzystania nowego dyskursu ekonomicznego przez elity jest traktat Edena-Raynevala o wolnym handlu z Anglia, który wszedł w życie w maju 1787 roku. Przyniósł on katastrofalne skutki ekonomiczne, które od razu przełożyły się na wrzenie społeczne. Francja została zalana tanimi produktami z angielskich manufaktur oraz surowcami pochodzącymi z angielskich kolonii. Przykładowo, import bawełny zwiększył się w latach 1786-1788 piętnastokrotnie! Na północy Francji doprowadziło to do zwolnień na 
masową skalę - ilość warsztatów w okresie 1785-1789 zmniejszyła się trzykrotnie (Marzagalli 2015). Nie dziwi więc stopień napięć klasowych o podłożu ekonomicznym, które spotykamy w okresie przedrewolucyjnym. Na wiosnę 1789 roku ceny chleba pobiły kolejny rekord, a robotnicy zarobkowi z miast wydawali na niego średnio 80\% swoich płac (w latach stabilnej koniunktury było to około 50\%; Marzagalli 2015). W 1788 roku naliczono 58 dużych zamieszek na tle żywieniowym, za to w pierwszych czterech miesiącach roku następnego aż 231! Ponad połowa $z$ nich wybuchła w najważniejszych miastach (Nicolas 2002). Przełożenie napięć ekonomicznych na walki klasowe jest niemalże mechaniczne.

\section{To, co społeczne, poza administracją}

Jak próbowaliśmy pokazać już wcześniej, omawiając słabość burżuazji, obieg pieniądza nie zmienia struktury klasowej, ale zostaje do niej dołączony. Najpierw jest bodźcem, na który muszą zareagować stare grupy społeczne, ale później staje się funkcją panowania, a nie kontrsiła. Odwrotne rozumowanie wynika z pewnego idealistycznego błędu metodologicznego. Podobnie jak nowe dyskursy nie są odbiciem stosunków społecznych, ale są narzędziami w rękach ścierających się sił, tak samo zmiany w jednej sferze - np. konsumpcji - sa tylko kolejnym elementem Starego Porządku: nie oznaczają przejścia do nowej struktury społecznej. Jednak w przypadku, w którym na poziomie teorii nie jesteśmy w stanie wyobrazić sobie elastycznej, dynamicznej i zróżnicowanej sieci władzy i dominacji, każda widoczna zmiana zmusza nas do ogłaszania nadejścia nowej epoki.

Tymczasem jest zupełnie odwrotnie. Porządek pieniądza nie następuje po porządku opartym na prestiżu, ale współgra z nim - dopiero zbadanie tej relacji daje jakąkolwiek wiedzę o społeczeństwie przedrewolucyjnym. Metoda „Wielkich Przejść” prowadzi donikąd.

$\mathrm{Na}$ samym początku zostawmy za sobą złudne wyobrażanie wszechmocy centrum (chociaż samo centrum produkuje dyskurs uprawomocniający je; chce być tak postrzegane). Król, Rada Królewska, jego najbliższe otoczenie oraz aparat administracyjny (przy założeniu, że przynajmniej część z niego można traktować jako przedłużenie władzy centralnej) musi nieustannie negocjować przynajmniej z dwoma innymi, wielkimi siłami społecznymi - potężną elita arystokratyczna/finansową oraz ze skomplikowaną siecią corps. Ruch negocjacji odbywa się wewnątrz maszyny, w której do osiagania swoich celów grupy używają zarówno instrumentów statusowych, jak i ekonomicznych. Takie rozumienie sprawy - ponownie, oparte raczej na grupach interesu niż pojęciach wyższego rzędu, takich jak klasa czy stan - pozwala uniknąć błędu metodologicznego w postaci uczasowienia statycznych porządków społecznych. Odchodzimy tu też od starych pojęć opisu, wypracowanych przez niemiecka historiografię, takich jak Standestaat, w których tylko prestiż pozycjonuje w stabilnej drabinie społecznej (Bossenga 2011). W zamian proponujemy iść droga multitudo, wydłużając tym 
samym w czasie pewien rodzaj średniowiecznej wrażliwości. Francja jest układanką różnorakich ciał, korporacji, stanów i przywilejów, które znajdują się w ciagłym ruchu. Maszyna działa, ponieważ umożliwia dosyć elastyczną formę konfigurowania i rekonfiguracji, terytorializacji i deterytorializacji - jednak cały czas musi splatać na nowo to, co społeczne. Stąd użyteczność pojęcia grupy interesu. Śledzimy je właśnie w tych krótkich spięciach, mikrokonfliktach, w których stara się regulować dany przepływ, chociaż za chwilę może ulokować się w innym miejscu, używając innych narzędzi (dyskursu, przywileju, pieniądza, siły), które jednak zawsze pozycjonowane są wobec interesu.

Francję przenika ogromna ilość ciał, corps, różnorodna sieć przywilejów prawnych i ekonomicznych. Corps definiowana jest jako personne morale, co oznacza, że prawnie może posiadać inną sprawczość niż jej poszczególni członkowie. Jest w stanie powoływać doyens, którzy reprezentują jej interesy, interweniować w sądach i posiada oficjalne ścieżki nacisku na rząd. Jest ciałem i personne morale w tym sensie, że „korporacja nie umiera nigdy”, ponieważ trwa niezależnie od pokoleń jej członków. Corps występują we wszystkich klasach, jest ich mnóstwo: od corps sądowniczych do chłopskich. I, co najważniejsze, ta sama osoba może pozostawać w różnych corps, uzgadniając korzyści, jakie czerpie z członkostwa, do realizacji bieżących interesów, które mogą być wyznaczane przez inny rodzaj zgrupowania - np. ekonomiczny czy prestiżowy.

Dopiero w kontekście ruchomej sieci korporacji należy rozwijać refleksję o przecinających się liniach prestiżu i pieniądza. Prześledźmy dla przykładu ruch centrum. Król dokonuje zabiegów, aby kontrolować korporacje, z jednej strony przez administracje, z drugiej przez uzyskania prawa do inkorporacji różnych grup. Jednocześnie kontroluje część corps, które pełnia najistotniejsze funkcje ekonomiczne, jak Kompania Wschodnio-Indyjska, będąca właściwie wirtualnym przedłużeniem rządu, i Ferme générale, która odpowiada za zbieranie części podatków. Z kolei niektóre corps zacięcie bronią swoich przywilejów, które przekładają się na korzyści ekonomiczne, oraz same decydują, kogo przyjmą do swego składu (Bossenga 2011). Ich siła przetargowa opiera się także na tym, w jakim stopniu wrośnięte są w tkankę społeczną Francji - na przykład to na ich siatce opiera się spisywanie kajetów zażaleń w 1789 roku.

Zmiany, które mogą wydawać się czysto ekonomiczne, nie występuja wobec sieci corps i przywilejów, ale w ich obrębie. W optyce Tocqueville’owskiej sprzedaż urzędów jest - ze strony króla - ruchem ekonomicznym umożliwiającym awans prestiżowy tych, którzy dokonali go już w strukturze klasowej. Jednocześnie ruch ten powoduje rozpad społeczeństwa przywilejów, bo „tytuł staje się tylko symboliczny”. Wiemy, że król, chcąc załatać skarb, wyczerpany wojna i utrzymywaniem imperium kolonialnego (a nie systemem świadczeń społecznych, jak twierdzi Tocqueville), wykorzystuje tradycyjny status urzędu ,jako trwałego przedmiotu", aby następnie upłynnić jego sztywną strukturę. Technicznie rzecz biorąc, urząd staje się rodzajem pożyczki, która później skutkuje pensja, rodzajem procentu. Trzeba jednak 
pamiętać, że w tej relacji siła polityczna dominuje nad ekonomiczną - król często „upomina się” o kolejną wpłatę „za urząd”, a w przypadku jej braku zapowiada jego wygaśnięcie. Ponadto dla wielu rodzin kupno urzędu okazuje się zupełnie nieopłacalne, np. w Bordeaux korzyści finansowe nie zwracają nawet 5\% sumy przeznaczonej na zakup. Pozornej możliwości awansu odpowiada więc ukryty mechanizm dystynkcji, który broni starych grup interesu przed upadkiem w uniformizująca przestrzeń relacji ekonomicznych. Ta dystynkcja, jak zobaczymy w przypadku szlachty, opiera się w dużej mierze na przemocy symbolicznej.

Przez siatkę relacji corps, ekonomii i prestiżu spróbujemy teraz spojrzeć na pojęcie szlachty. Ta siatka powinna umożliwić rozkład wspomnianego pojęcia przynajmniej na sześć części, w zależności od mikrokonfliktów, które je kształtują. Z jednej strony mamy więc szlachtę $z$ długa genealogia, która pozostaje nieufna w stosunku do grupy anobilis, szlachty $z$ awansu. Nobilitowani oficerowie wypracowują swój własny dyskurs merytokratyczny, aby obronić nowego szlachectwa - wiążą się więc interesami z profesjonalizacją wojska. Ale ruch reformy pociagga za sobą odpowiedź w postaci zwiększenia barier wejścia. Stara szlachta odpowiada, argumentując, że tylko genealogia poświęcenia i chwały przodków kształtuje dziecko chcące zostać oficerem. Druga oś przebiega na linii wieś-metropolia. Ponad połowa szlachty żyje na wsi - chociaż niektóre miasta, takie jak Rennes czy Aix-en-Provence określa się mianem „miast błękitnej krwi”. Ten podział nie pokrywa się z podziałem klasowym względem kapitału. Trzecia dystynkcja jest dystynkcją mobilności. Dla kupców i finansistów, którzy kupili urząd, posiadanie własnej ziemi i zamieszkanie na wsi pozostaje wyznacznikiem ich nowej szlacheckości. Kontrastuje to z praktykami wielkich elit senioralnych, które posiadaja dobra w różnych prowincjach i praktykują rodzaj „szlacheckiego nomadyzmu” (noble nomadism). Inny rodzaj podziału wiąże się z dostępem do dworu królewskiego, zarówno w aspekcie symbolicznym, jak i ekonomicznym. W pamiętnikach spotykamy się z wieloma opisami sytuacji, w których to szlachcic dostępuje zaszczytu krótkiego przedstawienia się królowi, przejazdu karoca po Wersalu. Co roku około 900 nowych rodzin uczestniczy w tym skomplikowanym procederze rytuału, obycia, zdobywania dostępu, testowania sieci kontaktów - wszystko to w ramach wyścigu o prestiż, który dla niektórych kończy się bankructwem. Rezerwuar zbytku i luksusu, jakim jest Paryż, pełni istotne funkcje stratyfikujące. Piątą osią podziału jest stosunek do Oświecenia, który często nakłada się na podział geograficzny generalnie o szlachcie z masywu centralnego nie wypada wypowiadać się inaczej niż per „ciemna”. Kolejny raz wydaje się, że szlachta jako jednolite pojęcie staje się widoczna dopiero z punktu końcowego procesu teleologicznego. Przedtem starzy nienawidzą nowych merytokratów, wieś szlachecka demonizuje zatrute luksusem miasto; wojskowi są niechętni tym z magistratów, oświeceniowcy gardzą ciemnogrodem, a wszyscy poza Wersalem i Paryżem 
plują na dwór, jednocześnie uczestnicząc w wyścigu o jego względy. Dopiero rewolucja pozwala szlachcie znaleźć (lub wynaleźć) jednolitość, której nie zaznała za ancien régime’u.

Powróćmy teraz krótko do rozważań teoretycznych. Ułuda spójnej konstrukcji systemu trzech stanów odsłania jej dyskursywny charakter. Statyczny model funkcjonuje jako narzędzie w ręku grupy interesu, która chce w ten sposób przedstawiać społeczeństwo narzucić mu nieruchomy obraz samego siebie. Widać to wyraźniej w dyskusjach współczesnych historyków, którzy zamiast pracować nad możliwie dynamicznym, elastycznym modelem, w którym przecinaja się linie klasowe i prestiżowe oraz koncentryczne kręgi corps, biją się o ustalenie punktu, „w którym rozpadł się podział stanowy, a zaczął klasowy”. W świetle naszych analiz takie myślenie wydaje się bezpłodne. Ma ono w sobie tyle mocy eksplanacyjnej, ile zastanawianie się nad tym, którego „czerwca skończył się w Polsce komunizm”.

\section{Cyrkulacja idei. Oświeceniowy mit}

Fetyszyzm pojęcia Oświecenia objawia się tym, że maskuje ono konkretne relacje społeczne, które się na nie składaja, jednocześnie ustanawiając się jako przedmiot sprawczy. Tymczasem jest to przedmiot skonstruowany, tak jak każdy inny. Jak widzieliśmy, Tocqueville buduje swój własny obraz Oświecenia, funkcjonalny w zakresie tez i podporządkowany metodom. W tym sensie o Oświeceniu należy raczej mówić jako o wytworze rewolucji. Dopiero ona dała mu pewien spajający, pragmatyczny cel oraz złączyła różnorodne pisma w jednolity program. To jedna wskazówka badawcza. Druga pochodzi od Kanta. Pamiętajmy, że gdy pisze on o Oświeceniu, zdecydowanie interesuje go aspekt formalny, kładzie nacisk na ruch, kanały transmisji, a nie treść czy ideologiczność. Element treściowy to dopiero widmo historiografii. Jak można empirycznie zbadać wpływ Oświecenia na rewolucję, pozostając jak najdalej od teoretycznego sposobu atakowania relacji wynikania? Można spróbować odpowiedzieć na pytanie: kto i jakie książki czytał? Jak wygląałał sposób ich dystrybucji oraz kto jak mógł je zrozumieć?

Większa cześć dzieł oświeceniowych podlegała cenzurze, dlatego badanie oficjalnych spisów ksiag mija się z celem - nikt nie wpisuje tam dzieł nielegalnych. Był to jeden z błędów metodologicznych, który popełnił Daniel Mornet w dziele Les origines intellectuelles de la Révolution française z 1933 roku, w zasadzie otwierającym powyżej wskazaną dyskusję. Jego kwerenda w 500 prywatnych bibliotekach wykazała tylko jedną kopię Umowy Społecznej Rousseau. Jednym z pomysłów na skorygowanie tego podejścia jest więc zebranie danych dotyczących książek wysyłanych do Francji, szczególnie ze Szwajcarii (dane z wydawnictwa Société typographique Neuchâteわ). Robert Darnton podjął się takiej pracy (Darnton 1995; 1982), z której wnioski można streścić następująco: chociaż w pierwszej trójce autorów, owszem, znajdują się Voltaire i d’Holbach, większą część czołówki zajmują książki opisujące skandale na dworze, pamflety 
i pornografia. Pozwala to na postawienie tezy o nikłym wpływie myśli oświeceniowej na wyobraźnię polityczną Francji - z wyłączeniem elit, które w takim ujęciu stają się zamkniętą grupa „adresatów-odbiorców”, osiemnastowieczną wersją „republiki listów”. Badania Darntona spotkały się z odpowiedzią m.in. Simona Burrowsa, który znacząco poszerzył zakres kwerendy (28 212 pozycji zbadanych przez Darntona, 410000 analizowanych przez Burrowsa; Burrows 2015). Nowsze badania znacznie dowartościowują pozycje zaliczające się do „wysokiego Oświecenia”, ale nie przynoszą odpowiedzi na interesujące nas pytanie - jak wyglądał most między Oświeceniem a rewolucją? Wpływ, badany ilościowo, wciąż musi opierać się na chwiejnej metodologicznie przesłance - że istniał w miarę jednolity pas transmisyjny idei między elitami a Francja. Odmienną sprawą pozostaje kwestia hegemoniczności grupy intelektualnej, oświeceniowej. Różnorodność pism oświeceniowych znika, gdy spytamy o to, w kontrze do czego są pisane - owszem, mają wspólnego wroga, ale nie świadczy to o ich jednolitości.

Być może warto poszukać więc innego motywu, który spełniałby funkcję katalizatora, a przynależałby raczej do mechanizmów władzy, aniżeli do sfery idei. W ramach pewnego eksperymentu teoretycznego uznajmy za taki „mechanizmy bezpieczeństwa” wypracowywane we Francji w osiemnastym wieku (Foucault 2010). Na czym polega funkcjonowanie władzy opartej na bezpieczeństwie? Interweniuje ona, zanim dojdzie jeszcze do czynu, potrzebuje więc statystyki, aby wszędzie, gdzie to możliwe, badać przeciętne poziomy zjawisk. Wszystkie ruchy wydarzają się więc w sieci prawdopodobieństwa, a reakcje władzy wynikają z kalkulacji zysków i strat względem obliczalnego optimum. Cały wywód Foucaulta ma na celu pokazać, w jaki sposób mechanizmy bezpieczeństwa synchronizowały się z wcześniejszymi - dyscyplinarnym i prawnym (Ratajczak 2013). Nam chodzi jednak o skonstruowanie pewnej intuicji na dosyć ogólnym poziomie teoretycznym, której sposoby weryfikacji należy jeszcze określić. Chodzi mianowicie o złączenie ze sobą w linowy model szeregu rozproszonych tez. Z jednej strony należy odnieść się do prawidłowości, która mówi, że wraz z rozwojem nowożytności w mainstreamowej filozofii politycznej refleksja na temat cnót jest konsekwentnie wypychana przez refleksję dotyczącą instytucji (Skinner 1978). Prosty paradygmat republikański dotyczący elit jest zaprojektowany co najwyżej dla miast i nie potrafi udźwignąć ciężaru, który pojawia się wraz z wejściem populacji do polityki.

Dopiero w tym świetle należy spojrzeć na związek rozwoju mechanizmów bezpieczeństwa i ich wpływu na rewolucję oraz kontrodpowiedzi ze strony samych rewolucjonistów. W takim ujęciu głębokie przemiany w obrębie technik władzy wpływają na wybuch rewolucji; z pewnością są matryca, w której działają rewolucjoniści - matryca ta pozwala im na wysunięcie własnych propozycji rządzenia populacja chociaż ich dyskurs funkcjonuje w kontrze do wcześniejszych technik władzy. Spójrzmy na Saint-Justa z Fragmentów o instytucjach republikańskich (Saint-Just 1954) - społeczna odpowiedź, która wyzbywa się 
elitarystycznych błędów ancien régime’u, wyrażona jest w języku starożytnych instytucji. Nie istnieje większy współczesny spartiata niż Saint-Just.

W naszej intuicji chodzi więc o to, by pomyśleć względnie szerokie, konieczne warunki możliwości rewolucyjnych mechanizmów władzy - i aby te konieczne warunki znaleźć w ancien régime’ie, unikając przy tym idealistycznego błędu wskazywania na Oświecenie. Dosyć ogólną podstawę do takich intuicji można znaleźć u Keitha Bakera, kiedy rozważa on stosunek „tego, co społeczne” i Oświecenia w kulturze osiemnastego wieku (Melching 1994). Pojęcie Oświecenia zostaje zdekonstruowane jako zbyt polisemiczne, jako Kampfbegriff, zmieniające się w zależności od kontekstu walki - następuje jednak ogólniejsza zmiana, na którą wskazuje Baker: pojęcia tego, co społeczne i społeczeństwa w zachodniej kulturze zastępują religię w funkcji „ostatecznego uzasadnienia porządku”, jako „leżące u podstaw ontologiczne i uogólnione uświadomienie sobie całości skomplikowanych wzajemnych powiązań, które uważamy za stanowiące podstawową rzeczywistość ludzkiej egzystencji”7. Śledzenie dominacji tego, co społeczne - szczególnie w paradygmacie bezpieczeństwa - wydaje się ciekawą perspektywą badawczą w zakresie przyczyn rewolucji francuskiej. Z pewnością ciekawszą niż łatanie dziurawych mostów między Oświeceniem a rewolucją.

\section{Molowe i molekularne. Subwersywność spójnego kodu}

Spróbujemy przestawić kilka intuicji badawczych, które pozwalają odejść od rozumienia sekularyzacji jako spójnego procesu, ale zachowują rozumienie kultury dawnej jako spójnego kodu. Tak aby w obrębie tego kodu możliwe były zarówno praktyki dyscyplinujące, jak i oporowe. Stawką naszych rozważań jest to, aby pokazać, że karnawałowy opór - wbrew interpretacjom, które czynią z Bachtnia konserwatystę - nie jest funkcją władzy. Karnawał nie jest odwróceniem, które tylko umacnia mechanizmy panowania, nie może być rozpatrywany jako mechanizm bezpieczeństwa ${ }^{8}$. Jest autonomicznym oporem. Aby to wykazać, posłużymy się badaniami Jean Howard dotyczącymi teatru w elżbietańskiej Anglii teatru jako pola bitwy (Howard 1994). Howard rozpoczyna swoją książkę od opisu choroby z 1603 roku, który sporządził protestancki lekarz, Edward Jorden. „The mother” jest choroba macicy i wedle Jordena „nawiedza szczególnie młode dziewczęta oraz wdowy, które, chcąc się wyleczyć, powinny unikać słodyczy, obfitych posiłków, zbyt długiego odpoczynku oraz wszelkich rozdrażnień, w szczególności nieszczęśliwej miłości”. Jeżeli ta jednak się zdarzy, należy natychmiast „znienawidzić obiekt pożądania lub w pełni mu się oddać”. Jorden przechodzi potem do opisu praktyk, które napawaja go wstrętem - po wioskach krążą rozmaici

\footnotetext{
${ }^{7}$ Cyt. za: Patrick Joyce: Czym jest to, co społeczne w historii społecznej? (Domańska 2010).

${ }^{8}$ Jak chce na przykład Charles Taylor, który operuje na spójnej linii sekularyzacji.
} 
guślarze, wiedźmy i znachorki, które mają swoje metody leczenia, ale jest to „nic innego jak teatr”; odległe od rzeczywistości „bezsilne zaklęcia”. Kończąc swój opis, Jordan przyznaje, że w wielu przypadkach leczenie nie pomaga. Lekarze moga wtedy odwołać się do ludowych praktyk - takich jak poproszenie syna, aby powiedział, że widzi w lustrze trzy diabły tańczące wokół chorej, które powoli się oddalaja - ponieważ „czasem taki rodzaj przedstawienia bywa bardzo pomocny”. Nie chodzi więc o to, by zdusić i zsekularyzować ludowy rytuał, ale by zapewnić sobie monopol na reprezentację, argumentujacc, że w przypadku jednej grupy (lekarzy) znak odsyła do zupełnie innego znaczonego. Podobne walki rozgrywaja się w obrębie teatru - nie idzie o samą treść przedstawiania, ale o to, które dyskursy, gesty, czasem hasła są sprawcze, a które puste i bezsilne. Walka toczy się więc o uznanie prawomocności praktyk, a nie o wyrugowanie niektórych z barwnego horyzontu społecznego.

Przenieśmy się teraz do lat trzydziestych osiemnastego wieku, do małego zakładu drukarskiego przy ulicy Saint-Severin w Paryżu (Darnton 2012). Paru robotników, których warunki pracy pogorszyły się znacznie wraz z koncentracją drobnego przemysłu i coraz bardziej powszechnym outsourcingiem, zrobiło tam „najśmieszniejszą rzecz”, jaka przytrafiła im się w życiu. Pewnego popołudnia dokonali oni masakry na kotach, które mieszkały wraz z nimi na terenie warsztatu i cieszyły się szczególnymi względami żony mistrza. Łapanie, okaleczanie, odgrywanie procesu kotów z podziałem na role, a następnie ich powieszenie były tak śmieszne, że robotnicy - w ramach wspólnotowej pantomimy - powtarzali tę scenę jeszcze wiele razy. Dlaczego dokonali masakry na kotach? Cała nowożytność usiana jest lokalnymi mikropraktykami religijnymi, które skrzętnie odnotowuje ludowy kalendarz. Trzysta lat po tym, jak sekularyzująca, dyscyplinująca siła reformacji kazała wysyłać na wsie inspekcje, by sprawdzały, w co naprawdę wierzą wierni, do czego naprawdę odsyłają ich praktyki religijne, na co wskazuje znak - Francja oddolna wciąż pali koty, goni je i morduje w wiosennych i karnawałowych rytuałach, w rytm kociej muzyki. Praktyka religijna jest żywa we wrażliwości robotników, którzy sięgaja po nią jako narzędzie oporu wobec władzy klasowej burżuazji. Mistrz i jego żona pozostają w jawnej dystynkcji wobec pracowników najniższego szczebla wskazuja na to wszystkie ich praktyki kulturowe i symboliczne. Garstka francuskich drukarzy dokonuje podobnej wolty co ludzie z południowych Włoch, którzy co lato odnawiają praktyki tarantyzmu - ukąszenia przez pająka, powodującego szaleńczy taniec, w którym wykrzykuje się swoje żale i w uświęcony sposób przyciąga uwagę całej społeczności. Wizyta w kościele potrafi uleczyć szał, ale czasem roztańczeni w manii mieszkańcy wsi kierują się ku ratuszowi i nieprzerwanie, przez dwa dni - każą władzy tańczyć wraz z nimi (De Martino 1971).

Wracamy teraz do teoretycznego aspektu naszych rozważań. Nie chodzi tu o proste wyliczenia - dla samej Francji istnieje szereg badań, które klasyfikują wielość oddolnych praktyk religijnych (Belmont 1973). Chodzi o umiejętność obrony pewnej intuicji - myślenie o sekularyzacji jako odgórnym, liniowym procesie nie jest pozbawione uzasadnienia, 
ale dotyczy poziomu molowego. Sekularyzacja jest obecna w podręcznikach filozofii, postępuje w złączonym łańcuchu elit. Ale na poziomie molekularnym pojęcie sekularyzacji traci znaczenie - podobnie jak podział na makro- i mikrohistorię. „Te dwie formy nie różnią się po prostu rozmiarami, jako formy małe i duże. Jakkolwiek jest prawda, że molekularne operuje na szczególe i przenika małe grupy, to prz̨ecież rozciaga sie na całe ciało społeczne” (Deleuze i Guattari 2015). Cała Francja utkana jest z mikropraktyk religijnych. Elitarna mniejszość będąca u władzy dokonuje kolejnych prób dyscyplinowania ich - i to w tym kontekście powinniśmy patrzeć na próby zagospodarowania tych wielościowych praktyk przez późniejszych rewolucjonistów. Wystarczy przyjrzeć się pismom dotyczącym kultu Istoty Najwyższej, aby zobaczyć, do jak wielkiej elastyczności zmuszona była interwencja poziomu molowego. Centrum musiało liczyć się z oddolnymi praktykami. Nie chciało ich zniszczyć, ale je kontrolować - ustalić punkt wspólnego rezonowania.

\section{Owernia i Mt. Blanc. Francja oddolna}

Jego Królewska Mość pragnie, aby z najdalszych zakątków jego królestwa i najbardziej zapadłych dziur wszyscy winni zostać zebrani, aby przekazać swoje życzenia i żądania. Wszyscy urodzeni lub naturalizowani jako Francuzi, co ukończyli lat 25, mają stałe zamieszkanie i są uwzględnieni w księgach podatkowych (cyt. za: Beaurepaire 2015).

Zeszyty zażaleń miały być stanowym pasem transmisyjnym, który wyraża wolę kolektywną ciał politycznych składających się na królestwo. Szlachta i duchowieństwo spisywała zeszyty na wyższym poziomie administracyjnym, baillages. Już pierwsze, podstawowe pytania statystyczne sprawiaja badaczce wielką trudność: jaka jest rzeczywista reprezentatywność kajetów jako źródeł? Ile osób wzięło udział w tym przedsięwzięciu? Dla przykładu, w późniejszym departamencie Nord mamy do czynienia z wahaniami od 9,7 do 100 poziomu procentowego partycypacji (przy średniej francuskiej przyjętej na 42\%; Grateau 2001). W Ile-de-France średni poziom partycypacji wynosi 22,5\%. Dokładne wnioski ilościowe sa szalenie trudne do ustalenia. Necker, mimo swojej przesadnej precyzji „nie zatroszczył się o kwestie podstawowe dla nowoczesnej analizy wyborczej: wcześniejsza rejestrację, spisy wyborców, obliczenia proporcji wyborczych - innymi słowy o wszystko to, co mogłoby pomóc w stworzeniu uporządkowanych i możliwych do porównywania statystyk" (Halévi 1987).

Bardzo trudno jest także określić stopień transmisji żądań oddolnych do kajetów. Zeszyty spisuje sekretarz, który ustala ogólny kształt kajetu dla całego zgromadzenia. Interesujące wydaja się przykłady, w których sam proces spisywania kajetu unaoczniał napięcia klasowe. W Varengeville, w bailliage Rouen obserwujemy, że 
wszyscy biedni mieszkańcy stawili się na zebraniu i podali swoje imiona. Wszyscy dobrowolnie wskazali swoich przedstawicieli. Ale widząc w zeszycie zbyt mało niedoli i biedy, która dotyczyła ich stanu, odmówili podpisania go, wykrzykując, że funt najzwyklejszego chleb kosztuje 3 sous i 6 dernier (Goubert i Denis 1964).

W Elliant, w senechausee Cocarneau udało się zdemaskować niedoreprezentowanie wsi w stosunku do miasta: „,wśród przedstawicieli stanu trzeciego Brytanii można znaleźć samych ludzi z miasta, ale nigdy ze wsi, co prowadzi do opresji chłopa i rolnika, którego potrzeby są nieznane, bo nigdy niekonsultowane" (Goubert i Denis 1964). Mamy do czynienia z dużą ilością bardzo różnych przypadków działań autonomicznych - począwszy od odmowy stawienia się na zebraniu (robotnicy dniówkowi z Orleanu), przez przykłady spisywania swoich własnych, oddzielnych zeszytów zażaleń, kończąc na próbach wykorzystania narzuconej sfery publicznej jako możliwości do bycia usłyszanym (Lefebvre 1962). Wszystkie te przypadki maja wspólne źródło - musiała istnieć mocna, praktykowana autonomia oddolna, która w momencie spięcia, konfliktu społecznego, stawała się podstawą do działań. Przeczy to podstawowym rozpoznaniom Tocqueville'a w tej dziedzinie. Nie ma jednak wattpliwości, że jeśli Tocqueville rzeczywiście, jak twierdzi, przebadał tyle zeszytów, to ma nad nami ogromną przewagę. Z 45 tysięcy tekstów, o których pisze, my mamy do dyspozycji 531 zbiorów z poziomu bailliage i senechaussee: 165 pochodzi od duchowieństwa, tyle samo od szlachty i 201 od stanu trzeciego (Beaurepaire 2015). Wystapić w kontrze do Tocqueville’a oznacza zadać pytanie: czy w zeszytach zażaleń naprawdę widać język Oświecenia i czy da się utrzymać teleologiczną tezę, że zapowiadaja one rewolucję? Problem badania zeszytów pod tym kątem dobrze obrazuje dyskusja między George’em V. Taylorem i Robertem Chartierem - mówi ona też coś o błędzie, jaki popełnia Tocqueville. Charakter badanych zbiorów kajetów wyznacza bowiem wnioski polityczne. Taylor skupił się na cabiers z najniższych zgromadzeń. W jego wizji stan trzeci żądał przede wszystkim konkretnych korzyści, jednocześnie okazując respekt w stosunku do tradycyjnych podziałów, tak jakby nie dokonała się praca Oświecenia: „Nasze badania wskazuja, że idee oświeceniowe były praktycznie nieistotne przed 5 maja, kiedy zebrały się Stany Generalne" (G.V. Taylor 1972). Chartier badał głównie zeszyty z poziomu bailliage i senechaussee, i dlatego w dużej mierze powtarza tezy Tocqueville'a (Chartier [b.d.]). Uznanie kajetów zażaleń za „głos oddolny” wiąże się z jeszcze jednym problemem. Badamy ostatni okres kultury dawnej, w której powielanie motywu nie wchodzi w konflikt z indywidualizacją. W obiegu znajduje się więc szereg „modeli” kajetów, które są powielane w większym lub mniejszym stopniu. Stąd dyskusja historiograficzna nad „fabrykacja opinii” - zajęcie stanowiska w tym sporze metodologicznym pozwala na dyskredytację takich czy innych wniosków politycznych dotyczących treści kajetów. Najsławniejszym przykładem jest tu Instruction donnée par S. A. S. monseigneur le duc d'Orléans, à ses représentants aux bailliages. Suivie de délibérations à prendre dans les assemblées, krążąca w liczbie około 100 tysięcy drukowanych 
egzemplarzy. Dawniej fakt ten stanowił argument za tezą o spiskowym, odgórnym wywołaniu rewolucji francuskiej. Paradoksalnie cień tego rozumowania zachował się do dziś - pojawia się zawsze wtedy, gdy zakłada się mechaniczną recepcję modelu wśród odbiorców. Tymczasem wzory kajetów należy traktować raczej jako oś, wokół której toczyły się lokalne dyskusje polityczne. W tym sensie stopień oporu wobec modelu staje się miernikiem oddolnej autonomii. Przeczy to tezie Tocqueville'a o atrofii społecznej.

Wydaje się, że sam fakt krążenia modeli nie zniekształca obrazu społeczeństwa francuskiego, jaki z nich wynika. Z jednym z najlepiej przyjętych wzorów kajetów mamy do czynienia w okolicach Rennes (Les Charges d'un bon citoyen de campagne). Jest to model, który wypływa ze środowiska patriotów i oferuje siatkę pojęciowa, w której można przedstawić bardzo wiele różnorodnych postulatów. W tym skrajnym przypadku wpływ modelu - pośredni lub bezpośredni - widać w około 40\% zeszytów z regionu (Grateau 2001). W innych przypadkach jest on zdecydowanie mniejszy.

Szczególnie ciekawa pozostaje jeszcze jedna kwestia. W przypadku zeszytów spisywanych na poziomie parafialnym stopień powielania modelu różni się znacząco, ale powtarza się pewna prawidłowość - znajdujemy w nich mnóstwo przykładów interwencji chłopskich dotyczących lokalnych problemów. Wskazuje się w nich na oddolną wiedzę, którą posiadaja spisujący, np. w sprawie mostów czy zbyt małej ilości drzew dających cień na drogach.

Francja oddolna potrafi się nie tylko bronić, ale wykorzystuje też mechanizmy prawne do poszerzania swojej autonomii. Autonomia ta wykuwała się w ogniu walk klasowych chłopi, nauczeni bitwami o dobra wspólne w okresie reakcji feudalnej, wykorzystują swoja wiedzę do działań politycznych, często próbując skorzystać z okazji, jaką daje zgromadzenie, by wymierzać sprawiedliwość i np. występować przeciwko sądom senioralnym (Beaurepaire i Giry-Deloison 1999).

Wnioski dotyczące zeszytów zażaleń spróbujemy teraz oświetlić z innej strony. Zestawimy je z opisem dwóch źródeł oddolnych z lata poprzedzającego rewolucje - pism chłopskich, z których jedno powstało w małej wiosce w Owernii, a drugie u podnóża Mount Blanc. W tym celu zreferujemy badania Vivian Gruder. Rozpoczyna ona swój artykuł dotyczący możliwości odtworzenia oddolnego głosu sprzed 1789 roku od opisu pewnego symbolicznego wydarzenia (Gruder 1993; 2007)9 . W lipcu 1788 lokalna gazeta z regionu Dauphine Nouvelle Extraordinaires de Divers Endroits donosiła, że przewoźnik na rzece Isere nie wpuścił do swojej łódki intendenta, który - na mocy prawa o rozwiązaniu lokalnych parlamentów z maja 1788 roku - miał założyć nowy sąd bailliage w pobliskiej Valence. Pytanie, które stawia Gruder, koresponduje z naszymi rozważaniami: czy możliwe jest, że zwykły człowiek z małej wioski

\footnotetext{
9 Wszystkie cytaty oraz główna oś wywodu pochodzą z książki i artykułu Vivian Gruder (Gruder 1993; 2007).
} 
miał tak rozwiniętą świadomość polityczną oraz jakiś rodzaj zaplecza autonomicznego, które pozwoliły mu na to oporowe zachowanie? Tradycja lefebvre'owska każe nam traktować autonomię chłopską w reakcyjny sposób - ich aktywność w roku następnym postrzega się jako oderwaną od głównego nurtu wydarzeń. Działania mają skupiać się wokół problemów lokalnych, mikrokonfliktów feudalnych, starć z lokalnymi grupami interesu. Podobny obraz bo tylko taką możliwość narzuca charakter źródła - wynika z zeszytów skarg. Sprawczość oddolna postrzegana jest więc albo jako reakcja na „rzeczywiste” ruchy polityczne na górze społeczeństwa, albo jako ochrona swoich prywatnych interesów o lokalnym zasięgu. Obydwa warianty nie są dla nas satysfakcjonujące.

Postaramy się argumentować za trzecim rodzajem sprawczości, którą określamy jako „sprawczość uczestnicząca”. Jest to sprawczość aktywna, oparta na zaangażowaniu w sprawy głównego nurtu, ale działająca na autonomicznych zasadach. Badanie dwóch pamfletów chłopskich z lata 1788 roku ma w tym wypadku jeszcze jedną zaletę metodologiczną - pozwala na upadek argumentu o aktywności oddolnej jako reakcji na bodziec „,z góry”, jak w przypadku odpowiedzi na administracyjną decyzję spisywania cabiers.

Geograficzne oddalenie obydwu wiosek od centrum ma z naszej perspektywy duże znaczenie. Pierwszy pamflet został spisany w Crevoux, w górach południowo-wschodniej Dauphine. Drugi pochodzi z równie odległego miejsca, górzystej doliny Limagne w Owernii. Skomplikowanie obiegu informacyjnego ma tu kluczowe znaczenie. Analizując go, spróbujemy przepędzić dwa duchy za jednym razem: duch Lefebvre’a każe nam patrzeć na chłopów jako odciętych od informacji - nie stać ich na książki, gazety; wieści o najważniejszych wydarzeniach przychodzą do wiosek raz na rok, są odczytywane przez księdza. Wielką wagę ma także zróżnicowanie językowe - czytający na głos musi tłumaczyć na patois, język lokalny, przez co kształtuje obraz wydarzeń. Drugi schemat rozumowania daje nam oczywiście Tocqueville, u którego pas transmisyjny idei jest spójny, a myśli elity oświeceniowej swobodnie spływają na dół - Francja oddolna gada Wolterem. Błędem obydwu tych perspektyw jest habermasowskie założenie o jednolitym charakterze sfery publicznej. Ten utopijny schemat dokonuje gwałtu na materiale źródłowym i - kolejny raz - zdecydowanie więcej zaciemnia niż wyjaśnia.

Tymczasem chłopi maja dostęp do informacji, ale ich przypływy są szalenie zróżnicowane. Na przykład w rejonie Dauphine intendent decyduje się na napisanie listu do ministerstwa, w którym spisuje listę wywrotowych pamfletów politycznych krążących wśród chłopów. Z kolei autor naszego dokumentu z Owernii musiał czytać jakieś gazety, znał pośrednio idee Monteskiusza oraz fragmenty pism byłych ministrów: Neckera i Calonne’a. Najważniejsze jest jednak to, że służyły mu one tylko jako fragmenty, z których złożył swoja własną filozofię społeczna. Chłopi z Crevoux wiedzieli z kolei o projektowanym podatku od ziemi i podatku pocztowym, planowanym podniesieniu podatku vingtiemes oraz o reformach gospodarczych i prawnych. Informacje te były odczytywane w lokalnym kościele, ale praca 
krytyczna chłopów wykonana na tej wiedzy pozostaje czysto autonomiczna. Przyzwyczajenie potocqueville’owskie każe nam niesłusznie stawiać obieg piśmienniczy nad obiegiem ustnym (a w obrębie obiegu pisemnego - monumentalne książki oświeceniowe nad wielościowymi drukami lotnymi). Tymczasem mnóstwo wiedzy oddolnej pochodzi właśnie z przekazu ustnego, przenoszenia informacji wraz z migracja. W latach osiemdziesiatych zdestabilizowanie gospodarki francuskiej przez elity i spekulantów prowadziło do wzrostu prekaryzacji. Przynajmniej 100 na 500 mieszkańców Crevoux opuszczało co roku swoją wieś, migrując za praca. To właśnie oni uczestniczyli wspólnie w zamieszkach 7 czerwca 1788 roku w Grenoble, gdzie udało im się powstrzymać odjazd lokalnych magistratów. Po dwóch tygodniach zanieśli te informacje do swojej wsi.

Stopień piśmiennictwa nie ma tu przełożenia na świadomość polityczną. Nie może być też postrzegany jako matryca wiedzy. Autonomia oddolna wydarza się w piosenkach, powiedzeniach, dyskusjach w karczmie. Nasze dwa pamflety pochodzą z rejonów o różnej alfabetyzacji. W Owernii wynosiła ona 30\% dla mężczyzn i $20 \%$ dla kobiet. Tymczasem w Crevoux jest to odpowiednio 75\% i $30 \%$. Nie wypływa to w żadnym stopniu na charakter argumentacji. Natomiast obydwa źródła wymagały pewnego „kulturowego pośrednictwa”. Aby powstać, Deliberation de la communaute de Crevoux musiały zostać spisane przez lokalnego prawnika. Odbija się to na dualistycznej strukturze dokumentu - oficjalne deklaracje polityczne przeplataja się z forma pamfletu. Natomiast relacja spisującego z autorami musiała być bliska - strony wzajemnie się kontrolowały. Spisujacy zabiegał bowiem o elekcję w lokalnych wyborach, musiał więc bardzo starannie i dokładnie oddawać głos chłopów. Chcąc z kolei przekonać ich do swoich racji, musiał dokonywać ciagłego, dwustronnego przekładu idei. Cały proces zakończył się sukcesem. Pamflet krążył, a na podstawie idei w nim zawartych parę miesięcy później chłopi z Crevoux wybrali dwóch deputowanych do zgromadzenia lokalnego, w tym swojego księdza. W przypadku Owernii to właśnie wiejski ksiądz notował pamflet Requete d'une societe' rustique a toutes les assembles generales, provinciales du royaume. Jego bliskość z ludźmi, których głos spisał, była wyraźna. W regionie znajdował się od 12 lat, problemy chłopów opisał z wielkim zaangażowaniem, często w emocjonalnym uniesieniu. Mówił zarówno w swoim, jak i ich imieniu, ale łączyła ich wspólna wrażliwość społeczna.

Przejdźmy teraz do treści pamfletów - poszukamy w nich autonomicznych schematów argumentacji. W dokumencie z Crevoux trzy takie schematy wymagają specjalnej uwagi: kwestia łącznia problemów oddolnych z centralnymi, wykorzystanie tradycji do walki politycznej oraz umiejętność subwersywnego użycia kodu religijnego kultury dawnej. Widać wyraźnie, że wśród spraw bieżących interesuje chłopów przede wszystkim sprawa nowych podatków. Umiejętnie łączą ją jednak z kwestia sądów i decyzją o powołaniu nowych zgromadzeń lokalnych. W tym celu używaja starego schematu „króla jako ojca ludu” (i ewentualnie złych doradców). Tyle że to swój stary, lokalny parlament (przypomnijmy: 
rozwiązany dekretem majowym) określą mianem ojca, le pere du peuple. To on właśnie chronił ich przed nadużyciami fiskalnymi. Taki zabieg teoretyczny przeczy tezie o indoktrynacji czy wiernopoddańczości królowi - jest dowodem krytycznej autonomii. Ludzie z Crevoux byli związani ze swoim starym zgromadzeniem materialnymi interesami. W pamflecie widać wyraźnie, że nie dali się też zwieść finansowym machinacjom - odwlekanie zawieszenia drugiego vingtieme traktowali (słusznie) jako obarczanie ich de facto nowym podatkiem. Powołując się na son gros bon sens, swój zdrowy rozsądek, obawiali się, że nowe zgromadzenie nie będzie „suwerenną władzą regionu”, ale przedłużeniem interesu rządu. Czytając ich pamflet, ma się wrażenie, że pod względem ziarnistości analizy - świadomości zróżnicowania takiego fenomenu jak „władza” - przewyższają Tocquville’a o głowę.

Autorzy z Crevoux wskazują także na źródła swojej argumentacji. Nie są to oświeceniowa centrala ani postulaty utopistów-marzycieli. Chłopi mówią o tradycji - można by powiedzieć: tradycji walk klasowych. Twierdza, że ich „ojcowie i dziadkowie” nie raz walczyli z władzą o sprawiedliwość. Jest w tym wiele racji. W szesnastym wieku region Dauphine sprzeciwił się swojemu parlamentowi i wyższym stanom podczas próby przeforsowania przywilejów fiskalnych dla najbogatszych. Jak się okazuje, to dawne wydarzenie było wciąż żywe w społeczności Crevoux - bliskie jej na tyle, by służyć jako źródło społecznej mobilizacji i jednocześnie na tyle dawne, by stanowić rezerwuar legitymizacji. Po raz kolejny widać, że pamięć mówiona rządzi się innymi prawami niż pamięć spisana, dlatego też może być użyta subwersywnie przeciwko skostniałemu centrum, przeciwko temu, co zdrzewiałe.

Subwersywnie udaje się też wykorzystać kod religijny. Społeczność z Crevoux pisze, że ich pamflet będzie się „spierał na rozum” z królem, ministrami i intendentem, tak jak „Hiob spierał się z Panem”. Wyrazistość kilku kwestii aż bije od tego stwierdzenia. Po pierwsze, chłopi swobodnie wykorzystuja schemat „dobry król - źli doradcy”. Ich refleksja nie ma nic z tej zidiociałej wizji polityki, w której najważniejszą rolę odgrywa charakter, intryga osobista, „dobry-zły człowiek”. Interesują ich problemy strukturalne, problemy, w których podstawowa rolę odgrywają „czynniki pozaludzkie”. Dylemat: albo oświeceniowa powaga, albo populistyczne oburzenie w stylu „bo on nakradł, ona miała romans”, jest fałszywy - nie rozpoznaje on roli śmiechu w kulturze dawnej. Karnawał może współistnieć ze strukturalną, oddolną analizą. Analizą, której stopień ogólności nie ma w sobie nic z ośweceniowej abstrakcji.

Dokument z Owernii zabiera nas w nieco inne rejony namysłu politycznego. Zbiorowy autor - w tym miejscu posiłkując się kapitałem symbolicznym księdza - powołuje się we wstępie na przykład Solona. Francja powinna zostać zorganizowana w taki sposób, aby chłopi byli reprezentowani we władzach, na różnych szczeblach, w „ilości przeważającej”, au nombre preponderant. Następnie poruszona zostaje kwestia podatków i świadczeń senioralnych. Region, z którego pochodzi źródło, był inaczej zorganizowany fiskalnie niż okolice Mount 
Blanc. Chłopi w Owernii nie płacili stałego podatku, ale nie mieli możliwości jego negocjacji, tak jak to było możliwe w Crevoux. Obciążenia podatkowe były w praktyce w pełni przenoszone na chłopów, samowola senioralna była zdecydowanie większa. W myśleniu politycznym z Crevoux lokalne instytucje były możliwe do przechwycenia i wykorzystania zgodnie ze swoim interesem. Dokument z Orwenii skupia się raczej na bardziej ogólnej analizie klasowej i dopiero na niej opiera możliwość wejścia w sojusz taktyczny z inną grupa społeczna. Według autorów pamfletu uprzywilejowani we Francji nie płacili wystarczająco dużo do wspólnego budżetu (dans la juste proportion du peuple): miał to być zaledwie 1\% ich średniego dochodu, podczas gdy chłopi oddawali $80 \%$, a burżuazja i rzemieślnicy 10\%. Wśród uprzywilejowanych wyróżnia się nową klasę - l’État civil - i to wokół niej kraży późniejsza refleksja. Autorzy twierdzili, że pierwotnie Francja dzieliła się na trzy stany - ale w chwili im współczesnej pojawiła się czwarta, która wiązała swoje interesy z państwem francuskim i starała się oddzielić od ludu, L'État-rustique. Ta nowa klasa naciskała na wprowadzanie nowych podatków oraz dążyła do wykupu ziemi i wkupienia się w szeregi starej szlachty. Nasz dokument z małej wsi wyprzedza o niemal rok sławny druk przedstawiajacy dwa stany na plecach trzeciego (jest w nim napisane: l'État rustique ecrase par les trois autres). Niemniej jednak widzimy w nim próbę budowy sojuszu chłopskiego z seniorami.

Argumentacja znowu rozgrywa się w słowniku grup interesów. Nasi autorzy twierdzili, że proponowane reformy będą też korzystne dla panów feudalnych - wówczas musieli oni poświęcać czas i środki, wykonując swoje obowiązki i opłacając podmioty lokalnej władzy (urzędników, sędziów). Mniej kosztowne okazać miało się dla nich zniesienie tak rozumianego feudalizmu, ponieważ mogło ono wyzwolić nowy rodzaj oddolnej energii gospodarczej, wynikającej z bardziej produktywnej pracy chłopów. Troska o model gospodarczy oparty na ziemi winna połączyć chłopów i posiadaczy. Autorzy pamfletu wyrażali nawet współczucie, że zwrot z inwestycji w ziemię maleje na rzecz spekulacji, jakiej można dokonać na rynkach finansowych. Przemawiała przez nich (dość perwersyjna) wizja ogólnokrajowego, neoliberalnego dobrobytu ${ }^{10}:$ mniejsze obciążenie chłopów stworzy impuls produkcyjny, ten przełoży się na wyższe dochody burżuazji i posiadaczy, którzy „wydadzą pieniądze”, co „wzbogaci mieszkańców”. Krytykuje się tu inwestycje, których efektem jest wydanie pieniędzy na luksus i prestiż symboliczny: „o wiele lepiej jest mieć płodne ziemie niż piękne miasta” (il est maintenant encore plus necessaire d'avior des campagnes fertiles, que des Villas decorees).

Obecna tu wizja dobrobytu gospodarczego opiera się także na wyeliminowaniu biedy. Nie zgadza się ona jednak z zatrudnianiem „ludzi wolnych” w manufakturach jako

10 Ważna w tym kontekście wydaje mi się uwaga Michała Pospiszyla: jeśli mamy tu do czynienia z autonomicznymi graczami, ten dziwny rodzaj neoliberalnej utopii może być przecież świadomą zagrywką, mająca na celu budowę tymczasowego sojuszu z panami feudalnymi - autorzy pamfletu maja przecież świadomość, że ze strony „sił postępu” nic ich absolutnie nie czeka. Byłby to więc kolejny przykład sięgania do rezerwuaru dyskursów w rozgrywce o bardzo konkretne i dobrze rozpoznane interesy. 
rozwiązaniem problemu. Wskazuje na fatalne warunki pracy, prekaryzację i ścisłą zależność od wahań koniunktury (poza tym „manufaktury produkuja na zbytek oraz... marnuja cenne drewno"). Pieniądze winny iść na sam dół społeczeństwa, które - zwolnione z ogromnych obciążeń finansowych - naturalnie, na poziomie strukturalnym, odpłaci się zwiększeniem produkcyjności pracy.

Najważniejszą zasadą podatkową (oprócz opodatkowania elit) winna być ta, zgodnie z która „obciążenie fiskalne chłopa nie może być wyższe niż najniższe w mieście”. Dodatkowo autorzy po raz kolejny łączą stare z nowym: klasztory powinny być coraz bardziej rozbudowywane, tak by pełniły funkcje szpitali (nieoddalonych zanadto od wsi), a pobór do wojska nie może odbywać się tylko w miastach, bo chłopi muszą wtedy za daleko jeździć.

Pamflet z Owernii w swej dziwnej hybrydyczności wymyka się rozróżnieniom Tocqueville’a. Obydwa rodzaje wiedzy, wewnętrzna i zewnętrzna, idą w kontrze do rozpoznań tocqueville’owskich. Zarówno wiedza, którą wynika z tego, co mówi źródło, a więc pewien projekt polityczny, pewna wizja Francji w nim zawarta, jak i wiedzą, którą źródło daje o rzeczywistości społecznej, z której się zrodziło, obala tezę Tocqueville’a o nieumiejętności „uczestnictwa ludu w wolności”. Republikańska wolność chłopów ma się zdecydowanie lepiej od wolności ich mitycznych oprawców z konserwatywnego przedczasu. Jest materialna, zrodzona w napięciu klasowym i oparta na rzeczywistych interesach. Hybrydowa, wielościowa forma tej wolności utrudnia klasyfikację - jakie poglądy, jakie -izmy reprezentuje oddolna Francja? Dość stwierdzić, że autorzy pamfletu z Owernii kończą swoje rozważania wizja reform, które zniosą prawa senioralne (za odszkodowaniem), skończą z monopolem pańskim na młyn, piece itp., ale zachowają tytularny i prestiżowy charakter senioralności, która opłacana będzie z rent i należności od obrotu ziemia. Tradycja jest bowiem rozumiana jako rezerwuar, którego konkretne elementy (jak wyobrażenie Solona) aktualizują się dopiero w polu walki politycznej. Dopiero takie ujęcie teoretyczne pozwala nam zrozumieć ogromną różnorodność i bogactwo form oddolnego myślenia. Hegemoniczna historiografia, przepełniana trwoga przed masami, nie zna takiej metodologii.

\section{Zamiast zakończenia: mikropolityka historii i segmentacja. Zabijać czy wymijać Ojca?}

Przez cały czas patrzyliśmy na hegemoniczne centrum w badaniach nad rewolucja. Albo inaczej: współczesna, liberalna akademia kazała nam patrzeć na Tocqueville’a, ponieważ wciąż wystawia go na widok w obronie swoich granic. Nasz ruch wiąże się więc z pewną pułapka, w którą wpadliśmy jednak zamierzenie, twierdząc od początku, że będziemy schodzić wraz z Tocquevillem na coraz niższe poziomy analizy, podważając jego konkretyzacje - ale na jego 
zasadach. W ruchu tym cały czas patrzyliśmy na władzę. A władza chce przecież, by na nią patrzeć, chce być widzialna, bo tylko zasilona spojrzeniem staje się prawomocna. Miara naszego sukcesu nie będzie więc wyjście z pułapki. Efektem pracy badawczej, będącej jednocześnie walką polityczna, ma być co innego - Tocqueville ma wyjść z tej potyczki osłabiony, a my wzmocnieni możliwie szeroko aplikowalnym zestawem krytycznym, który będzie można zastosować do innych starć z hegemoniczną historiografia. Odrębną kwestią pozostaje jednak wciąż wyjście z pułapki.

Wațliwość, która rodzi się po wykonanej pracy, ma charakter strategiczny. Nawet jeśli udało nam się rozmontować jedną maszynę teoretyczną, to nie wybudowaliśmy własnej, autonomicznej. Możliwą odpowiedzią - która z różnych względów nas teraz nie satysfakcjonuje - jest stwierdzenie, że emancypacyjna historiografia nie rości sobie praw do systemowości i całościowych ujęć, ponieważ powielałaby tym samym naturę tej dyscyplinującej. Zamiast tego ma śledzić pęknięcia, ciemne miejsca, to, co umyka opisowi i klasyfikacji. Tylko w ten sposób jest w stanie dokonać exodusu, zignorować Ojca, zamiast tracić siły na walkę z nim na jego zasadach ${ }^{11}$.

Być może warto przemyśleć kwestię drogi pośredniej, która nie ma w sobie nic z pośredniości liberalnego kompromisu, ale jest bliższa platońskiemu pomiędzy, methexis znajduje się w ciagłym ruchu między dwoma członami dialektycznymi. Zalążki takiej perspektywy można by wydobyć z ruchów, które wykonaliśmy w tej pracy - jednocześnie schodząc za Tocqueville'em ku rozważaniom, które on sam dyktował, oraz wyznaczając pytania badawcze skierowane w stronę myślenia konserwatywnego i w tym sensie od niego zależne. Ale ruch partyzancki, dziecięcy i być może prawdziwie wyzwalający, polegałby na tym, aby w ramach owych pytań badawczych - z samego dna Tocqueville'owskich konkretyzacji przeprowadzić atak przy użyciu materiału historycznego przepracowanego przez kategorie, których hegemon nie zna. Wiele z tego, co powiedzieliśmy o społeczeństwie ancien régime’u, można by opisać w kategoriach operaistycznych, deleuzjańskich lub anarchistycznych. W naszym przekonaniu tego typu praca w zalążku została wykonana - albo przynajmniej rozpisana.

Kwestią otwartą pozostaje to, czy takie podwójne działanie spełniałoby rolę rzeczywiście emancypacyjnej strategii dla historiografii. Nasza intuicja podąża za ostatnim gestem z Uczty. Być może trzeba umieć pisać komedie i tragedie jednocześnie. Dopiero wtedy zarówno komediopisarz jak i tragik usną na naszych kolanach.

\footnotetext{
${ }^{11}$ Jest to w jakimś sensie chęć powtórzenia gestu Benjamina z eseju o Kafce: chodzi o snucie takich opowieści, „,jakie ma w ustach Szeherezada”, opowieści, które wymykają się władzy i które „,cierpliwie deterytorializują prawa ojców i urzędników”. (Zob. Benjamin 2012, 245; Pospiszyl 2016, 196-197).
} 


\section{Wykaz literatury}

Beaurepaire, Pierre-Yves. 2015. „The view from below. The 1789 cahiers de doleances.” W The Oxford Handbook of the French Revolution. Red. David Andress. Oxford: Oxford University Press.

Beaurepaire, Pierre-Yves i Charles Giry-Deloison. 1999. La terre et les paysans: France, GrandeBretagne, XVIIe-XVIIIe siècles. Neuilly-sur-Seine: Atlande.

Benjamin, Walter. 2012. Konstelacje: wybór tekstów. Tłum. Anna Wołkowicz, Adam Lipszyc. Kraków: Wydawnictwo Uniwersytetu Jagiellońskiego.

Belmont, Nicole. 1973. Mythes et croyances dans l'ancienne France. Paris: Flammarion.

Bossenga, Gail. 1988. „Protecting Merchants: Guilds and Commercial Capitalism in Eighteenth-Century France." French Historical Studies 15 (4): 693-703. doi: $10.2307 / 286553$.

Bossenga, Gail. 2011. „Estates, Orders and Corps.” W Oxford Handbook of the Ancien Regime. Red. William Doyle. Oxford: Oxford University Press.

Burrows, Simon. 2015. „Books, Philosophy, Enlightment.” W The Oxford Handbook of the French Revolution. Red. David Andress. Oxford: Oxford University Press.

Carrière, Charles, Marcel Courdurié i Ferréol Rebuffat. 1968. Marseille, ville morte. La peste de 1720. Marseille: M. Garçon.

Chartier, Roger. [b.d.]. „Cultures, Lumières, doléances : les cahiers de 1789”. Revue d'histoire moderne et contemporaine 28-1: 68-93.

Chaussinand-Nogaret, Guy. 1987. The French Nobility in the Eighteenth Century. (La Noblesse Au 18. Siecle). From Feudalism to Enlightenment. (Repr.). Cambridge-New York etc.: Cambridge Univ P V.

Clay, Lauren R. 2015. „The Bourgeoisie. Capitalism, and the Origins of the French Revolution." W The Oxford Handbook of the French Revolution. Red. David Andress. Oxford: Oxford University Press.

Darnton, Robert. 1982. The Literary Underground of the Old Regime. Cambridge-Mass.: Harvard University Press.

Darnton, Robert. 1995. The Forbidden Best-Sellers of Pre-Revolutionary France. New York: W.W. Norton.

Darnton, Robert. 2012. Wielka masakra kotów i inne epizody francuskiej historii kulturowej. Tłum. Dorota Guzowska. Warszawa: Wydawnictwo Naukowe PWN.

De Martino, Francesco. 1971. Ziemia zgryzoty. Prayczynek do historii sycia religijnego potudniowych Włoch. Tłum. Wojciech Marucha. Warszawa: Książka i Wiedza.

De Vito, Christian. 2016. Labour Flexibility and Labour Precariousness as Conceptual Tools for the Historical Study of the Interactions Between Labour Relations. https://lra.le.ac.uk/handle/2381/33561.

Deleuze, Gilles i Félix Guattari. 2015. Tysiac plateau. Kapitalizm i schizofrenia II. Red. meryt. Joanna Bednarek. Warszawa: Fundacja Nowej Kultury Bęc Zmiana.

Doyle, William. 1980. Origins of the French Revolution. Oxford-New York: Oxford University Press. 
Domańska, Ewa. Red. 2010. Teoria wiedzy o przeszłtości na tle wspótczesnej humanistyki. Antologia. Poznań: Wydawnictwo Poznańskie.

Dupâquier, Jacques, Alfred Sauvy i Emmanuel Le Roy Ladurie. 1988. Histoire de la population française. Paris: Presses universitaires de France.

Foucault, Michel. 2010. Bespieczeństwo, terytorium, populacja. Wykłady w Collège de France 1977_ 1978. Red. Michel Senellart, François Ewald i Alessandro Fontana. Tłum. Michał Herer. Warszawa: Wydawnictwo Naukowe PWN.

Furet, François. 1994. Prawdżiny koniec Rewolucji Francuskiej. Tłum. Barbara Janicka. KrakówWarszawa: Znak; Fundacja im. Sefana Batorego.

Goubert, Pierre i Michel Denis. 1964. 1789: les francais ont la parole... : cabiers de doleances des etats generaux. Paris: Julliard.

Grateau, Philippe. 2001. Les cabiers de doléances: une relecture culturelle. Rennes: Presses Universitaires de Rennes.

Greenfeld, Liah. 2001. The Spirit of Capitalism: Nationalism and Economic Growth. CambridgeMass.: Harvard University Press.

Gruder, Vivian R. 1993. „Can we Hear the Voices of Peasants? France, 1788.” History of European ideas 17 (2-3): 167-190.

Gruder, Vivian R. 2007. The Notables and the Nation: The Political Schooling of the French, 1787 1788. Cambridge-Mass.: Harvard University Press.

Halévi, Ran. 1987. „La monarchie et les élections: position des problems”. W The French Revolution and the Creation of Modern Political Culture. Oxford-New York: Pergamon Press.

Howard, Jean E. 1994. The Stage and Social Struggle in Early Modern England. London- New York: Routledge. http:/ / public.eblib.com/choice/publicfullrecord.aspx?p=179419.

Koselleck, Reinhart. 2001. „Miniona przeszłość wczesnej nowożytności”. W Semantyka Historyczna. Tłum. Wojciech Kunicki. Poznań: Wydawnictwo Poznanskie.

Lefebvre, Georges. 1962. Études orléanaises. Paris: Commission d'histoire économique et sociale de la Révolution.

Lucas, Colin. 1973. „Nobles, Bourgeois and the Origins of the French Revolution”. Past \& Present 60 (August): 84-126.

Marczewski, Paweł. 2012. Ucsynić wolność nieuchronnq. Watki republikańskie w myśli Alexisa de Tocqueville'a. Warszawa: Wydawnictwo Instytutu Filozofii i Socjologii PAN.

Marzagalli, Silvia. 2011. „The French Atlantic World in the Seventeenth and Eighteenth Centuries." W The Oxford Handbook of the Atlantic World: 1450-1850. Red. Nicholas Canny i Philip Morgan. New York: Oxford University Press.

Marzagalli, Silvia. 2015. „Economic and Demographic Developments.” W The Oxford Handbook of The French Revolution. Red. David Andress. Oxford: Oxford University Press.

Maza, Sarah. 2003. The Myth of the French Bourgeoisie: an Essay on the Social Imaginary, 1750-1850. Cambridge: Oxford University Press.

Melching, Willem. 1994. Main Trends in Cultural History: Ten Essays. Amsterdam-Atlanta, GA: Rodopi. 
Morrisson, Christian. 2007. „La production française au XVIIIe siècle : stagnation ou croissance ?" Revue européenne des sciences sociales. European Journal of Social Sciences XLV-137: 153-165. doi:10.4000/ress.224.

Nicolas, Jean. 2002. La rébellion française: mouvements populaires et conscience sociale : (1661-1789). Paris: Seuil.

Pospiszyl, Michał. 2016. Zatraymać historie. Walter Benjamin i mniejszościowy materializ̨m. Warszawa: Instytut Badań Literackich PAN.

Ratajczak, Mikołaj. 2013. „Genealogia biopolityki. Biologia państwa”. Praktyka teoretyczna 9: 299-234.

Saint-Just, Louis-Antoine-Léon. 1954. Wybór pism. Oprac. Izabela Bibrowska. Tłum. Jan Ziemilski, Bolesław Kulikowski. Warszawa: Książka i Wiedza.

Schmitt, Carl. 2012. Teologia politycznna i inne pisma. Tłum. Marek Cichocki. Warszawa: Wydawnictwo Aletheia.

Skinner, Quentin. 1978. The Foundations of Modern Political Thought. Cambridge-New York: Cambridge University Press.

Taylor, Charles. 2007. A Secular Age. Cambridge-Mass.: Belknap Press of Harvard University Press.

Taylor, George V. 1972. „Revolutionary and Nonrevolutionary Content in the Cahiers of 1789: An Interim Report." French Historical Studies 7 (4): 479. doi:10.2307/286194.

Tomba, Massimiliano. 2013. Marx's Temporalities. Leiden-Boston: Brill. http://booksandjournals.brillonline.com/content/9789004236790.

Traverso, Enzo. 2014. Historia jako pole bitwy. Interpretacja przemocy w XX wieku. Tłum. Światosław Florian Nowicki. Warszawa: Instytut Wydawniczy Książka i Prasa.

Traverso, Enzo. 2016. Mélancolie de gauche: la force d'une tradition cachée (XIXe-XXIe siècle). Paris: La Découverte.

Vinci, Paolo. 2014. „Abstrakcja określona”. W Marks. Nowe perspektyny. Red. Libera Università Metropolitana. Tłum. Sławomir Królak. Warszawa: Wydawnictwo Naukowe PWN.

Wahnich, Sophie. 2015. In Defence of the Terror: Liberty or Death in the French Revolution. Tłum. David Fernbach. New York-London: Verso.

Weir, David R. 1991. „Les crises économiques et les origines de la Révolution française”. Annales. Histoire, Sciences Sociales 46 (4): 917-947. doi:10.3406/ahess.1991.278986. 
Gabriel Klimont - student filozofii i historii w ramach MISH UW. W Instytucie Historycznym przygotowuje pracę magisterską na temat metodologii badań nad ludźmi luźnymi w Warszawie końca osiemnastego wieku. Redaktor afiliowany Praktyki Teoretycznej.

\section{DANE ADRESOWE:}

Kolegium Międzyobszarowych Indywidualnych Studiów

Humanistycznych i Społecznych UW

ul. Dobra 72

00-312 Warszawa

EMAIL: gklimont@gmail.com

CYTOWANIE: Klimont, Gabriel. 2017. Polityczność metodologii a polityczność przedrewolucji. Tocqueville, emancypacja i krytyka konserwatywnej historiografii. Praktyka Teoretyczina 1(23): 24-61.

DOI: $10.14746 /$ prt.2017.1.2

\section{AUTHOR: Gabriel Klimont}

TITLE: The Politicalness of Methodology and the Politicalness of the Pre-revolution. Tocqueville, Emancipation and the Critique of Conservative Historiography.

ABSTRACT: This article presents a critique of mechanisms employed by conservative historiography. It is grounded in an analysis of selected discussions in the field of social history which focus on the last period of the Ancien Régime. Furthermore, the article presents a methodological and conceptual analysis of contemporary historical polemics. The aim is to transform problems that are typically considered as strictly historical into philosophical problems and to identify their political stakes. As a result, schemes implicit to conservative narration are sketched, and ideas for an interdisciplinary, emancipatory historiography are discussed. The envisioned perspective would simultaneously draw from the achievements of history from below, leftist macro-history and a philosophical critique of history.

KEYWORDS: French Revolution, Tocqueville, Walter Benjamin, methodology of history, history from below 